\title{
Two Major Heavy Rain/Flood Events in the Mid-Atlantic: June 2006 and September 2011
}

\author{
CHRISTOPHER M. GITRO \\ National Weather Service, Johnson City, New York \\ MICHAEL S. EVANS \\ National Weather Service, Johnson City, New York \\ RICHARD H. GRUMM \\ National Weather Service, State College, Pennsylvania
}

(Manuscript received 13 December 2013; review completed 27 March 2014)

\begin{abstract}
In June 2006, significant flooding and flash flooding impacted much of the mid-Atlantic region as a continuous supply of deep tropical moisture moved north from the subtropical Atlantic ahead of a slowmoving cold front. A 3-day period of heavy rain resulted in nearly $38.1 \mathrm{~cm}(15 \mathrm{in})$ of rain across portions of the northern mid-Atlantic with record flooding along the mainstem Susquehanna and Delaware Rivers. In September 2011, moisture associated with the remnants of Tropical Storm Lee resulted in a 24-h period of heavy rain over which rainfall totals approached $30.3 \mathrm{~cm}(12$ in) across portions of central New York and northern Pennsylvania. Numerous river-stage records that were set in the June 2006 event were shattered along the mainstem Susquehanna River during the September 2011 flood. Damage estimates resulting from the flooding in both events were $>2$ billion dollars, and 22 lives were lost. Multiple counties across the northern mid-Atlantic were declared disaster areas.

Both flood events were investigated to identify the similar meteorological features and patterns responsible for extreme rainfall. Several crucial similarities were identified that likely combined to produce historic socioeconomic and environmental impacts. One of the similarities was that each event had a well-established atmospheric river in place that provided the uninterrupted supply of deep tropical moisture. Additionally, although these events displayed many of the large-scale characteristics identified in previous flash flood classification schemes, both events were associated with the presence of coastal fronts that appeared to make these cases different from many otherwise similar and previously documented flood cases.
\end{abstract}

\section{Introduction}

a. Background

Flash flooding remains one of the most serious and life-threatening weather-related hazards across the United States. Each year, flash flooding ranks as one of the biggest contributors of weather-related fatalities [National Oceanic and Atmospheric Administration (NOAA 1995-2012); National Weather Service (NWS 2012a)]. Knowledge of favorable flood and flash flood-producing patterns can assist forecasters in anticipating potential high-impact flood events days in advance. With the vision of the NWS being heavily focused on building a weather-ready nation (NOAA 2014), providing comprehensive decision-support ser- vices to users in anticipation of high-impact weather events has become a top priority for the agency.

Flash flood forecasting in its infancy stages revolved around recognition of favorable synoptic patterns capable of large-scale, heavy rainfall production. In a landmark paper, Maddox et al. (1979; hereafter referred to as M79) described three patterns capable of large-scale flash flooding based on surface front orientation and upper-level height characteristics for areas east of the Rocky Mountains. On the synoptic scale, M79 showed that synoptic-type flash flood environments were characterized by a highly amplified trough to the west of the flash flood region. Under this configuration, a continuous supply of deep moisture is transported north in southerly or west-southwesterly 
flow aloft. At the surface, a slow-moving cold front or stationary boundary often is positioned in a southwest to northeast orientation. Low-level convergence along the boundary, coupled with the passage of midlevel short-wave troughs, results in warm-sector convection, while steering flow oriented parallel to the low-level front allows cells to travel over the same areas repeatedly.

In the frontal-type flash flood environment, the upper-level pattern often is dominated by ridging aloft. Along the surface, a slow-moving warm front or stationary boundary separating warm, moist, unstable air to the south from cool, stable air to the north typically is oriented in an east-west configuration. Thunderstorm initiation normally develops in advance of a short-wave trough moving along the northern periphery of the upper ridge. Approaching upper-level forcing, combined with increasing isentropic ascent from a strengthening low-level jet (LLJ) transporting high equivalent potential temperature $\left(\theta_{e}\right)$ air over the frontal zone, results in favorable conditions for heavy rainfall production and possible flash flooding. Frontaltype events typically reach maximum intensity during the overnight when the LLJ often is strongest.

Flash flood forecasting through much of the 1980s and 1990s depended heavily upon recognition of the patterns outlined in the above M79 study (Funk 1991; Davis 2001), with many of these concepts still operationally relevant today. In the mid-to-late 2000s, new studies by Grumm and Holmes (2007) and Stuart and Grumm (2009) refined the definition of the synopticscale patterns capable of widespread flash flooding across the eastern United States by building upon the original concepts described by M79. In the 2007 study, the authors constructed standardized anomaly (SA) composites (Grumm and Hart 2001a,b) for both frontal- and synoptic-type flash flood environments. They showed that synoptic events often were characterized by precipitable water (PWAT) and $850-\mathrm{hPa} v$-wind anomalies of at least two standard deviations above normal. As for frontal events, an analysis showed these events also had 850 -hPa $u$-wind anomalies of roughly two standard deviations above normal. For both event types, the wind anomalies suggest that moisture advection from either the Gulf of Mexico or western Atlantic is critically important for heavy rain production in the mid-Atlantic region. Furthermore, the study also defined the synoptic-tropical flash flood pattern in which moisture associated with a decaying tropical system becomes entrained in strong southwesterly low-level flow. While the upper-level and near-surface environments resemble the synoptic pattern, higher amounts of tropospheric moisture associated with the decaying tropical system lead to heavier rain and more significant flooding in synoptic-tropical events.

Mesoscale influences also have been shown to play a significant role in heavy rain and flash flood production. In the original M79 study, the authors described the mesohigh flash flood environment in which an outflow boundary from previous convection serves as a major focus for renewed thunderstorm development. In this scenario, the upper-level pattern largely resembles that of the frontal-type environment, with upper ridging overhead; however, a key difference is that the near-surface forcing contribution results from an outflow boundary as opposed to a stalled or slow-moving, synoptic-scale front. In another documented case of mesoscale influences along the East Coast, Bosart et al. (1972) introduced the concept of a New England coastal front where a mesoscale baroclinic zone forms ahead of a northward-moving lowpressure system traveling up the East Coast. The development of strong thermal gradients in association with cold-air damming to the east of a major mountain range (Bell and Bosart 1988), combined with warm, moist, easterly flow in advance of the northward lifting cyclone, can create a significant mesoscale thermal gradient just inland from the coast. This pattern is not restricted to just New England (Bosart 1984). In another study, Bosart and Dean (1991) showed that a surface front extending north from the extratropicaltransitioning Hurricane Agnes circulation combined with cold-air damming to the east of the Appalachians to produce a strong, low-level frontal circulation. This system resulted in record flooding from the central mid-Atlantic north through the Susquehanna and Chemung River Valleys of Pennsylvania and Upstate New York. Numerous other studies also have investigated a wide-range of mesoscale environments capable of producing heavy rainfall (e.g., Atallah and Bosart 2003; Colle 2003).

Several studies also have highlighted the difficulty associated with flash flood forecasting across the eastern third of the United States. In a study outlining flash flooding in the Eastern Region of the NWS, LaPenta et al. (1995) described the inherent forecast difficulties enhanced by extensive urbanization, terrain-anchoring mechanisms, and enhanced runoff due to frozen ground and complex terrain. In a separate study, Gitro (2012) discussed how the central New York and northeastern Pennsylvania areas are com- 
posed of numerous yearlong, fast-responding streams that quickly can reach or exceed flood stage when adequate precipitation or snowmelt occurs. In addition, both the Atlantic Ocean and Gulf of Mexico serve as large moisture source regions. This moisture, combined with the region's steep terrain, leads to flash flooding being the single greatest hazard to residentsbased on the number of flood-related fatalities during the period of study (Gitro 2012). Other studies done at the Binghamton (BGM), New York, weather forecast office (WFO; Jessup and DeGaetano 2008) have documented the inherent difficulties associated with flash flooding across both the BGM WFO county warning area (CWA) and the northeastern United States (Jessup and Colucci 2012). However, the occurrence of events with both major river- and flash-flooding remains rare. As a result, documentation of these flooding events is needed to ensure adequate recognition of similar patterns so timely and accurate decision-support services can be provided to government and emergency preparedness personnel, as well as the general public.

\section{b. Purpose}

The purpose of this paper is to investigate two major flash flood events that impacted the northern mid-Atlantic region. Case studies of the June 2006 and September 2011 flood events will be compared in an effort to document key synoptic and mesoscale features that resulted in heavy rain production and significant flooding. In addition, both events also were associated with record-breaking river flooding. In terms of the top 20 river floods in the mid-Atlantic region based on the total number of river forecast points at or above flood stage, the June 2006 (September 2011) flood event ranks 6th (4th) all-time, with 92 (108) total gaged locations at or above flood stage [Middle Atlantic River Forecast Center (MARFC) 2013]. For the purpose of this paper, the term "river flooding" refers to flooding along area rivers and streams resulting in high flow, overflow, or inundation by water that causes a threat to both life and property. These events normally are handled by the issuance of point-specific river flood warnings for points that have pre-established forecast and warning services. Meanwhile, flash flooding refers to rapid, life-threatening rises of water, which typically are of shorter duration (i.e., $\leq 6 \mathrm{~h}$ ) and require immediate action for the protection of life and property. These events are handled by the issuance of flash flood warnings that can be disseminated for any area within the confines of a WFO's CWA (NWS 2011).

In preparing for this study, a review of several archived area forecast discussions from WFO BGM prior to the June 2006 event indicated a high likelihood for flash flooding but low expectations of major river flooding along the mainstem rivers within WFO BGM's hydrologic service area. Perhaps forecasters thought that the rainfall would not reach magnitudes large enough to result in major river flooding or that the expected heavy rainfall would not be widespread enough to cause a significant response on mainstem rivers. However, a detailed examination of factors influencing the forecaster's thought processes and decision-making during the June 2006 flood event is beyond the scope of this study. The fact that expectations were low for significant river flooding suggests that many forecasters were caught by surprise by the sheer scope of river flooding that occurred along the mainstem Susquehanna and Delaware Rivers in June 2006. Although expectations for the September 2011 event focused on the likelihood of both significant flash flooding and river flooding, preliminary forecaster consensus between the NWS's MARFC and WFO BGM placed the highest threat of flooding across the Chemung River basin (Fig. 1), approximately $80-120 \mathrm{~km}(50-75 \mathrm{mi})$ west of where the heaviest rains actually fell. This study will focus on the meteorological factors that led to heavy rainfall in both cases, with the understanding that the heavy rainfall was responsible for both flash and river flooding in each case. A detailed examination of the hydrological factors associated with these cases is beyond the scope of this work; however, the reader should keep in mind that hydrological factors also played a significant role in how both of these events evolved. In addition, both cases will be compared to conceptual models described by M79 and Stuart and Grumm (2009) to determine if the events of June 2006 and September 2011 were similar to previously documented heavy rain and flash flood patterns for the East Coast. The paper is organized as follows: the data and study methods will be discussed in section 2 ; in section 3 a brief overview of both northern mid-Atlantic flood events is given; in section 4 a comparison of the synoptic environments is presented; a discussion highlighting the unique coastal boundary setup that both events possessed is reserved for section 5; finally, a brief summary reviewing key findings and recommendations for detection of similar events is offered in section 6 . 


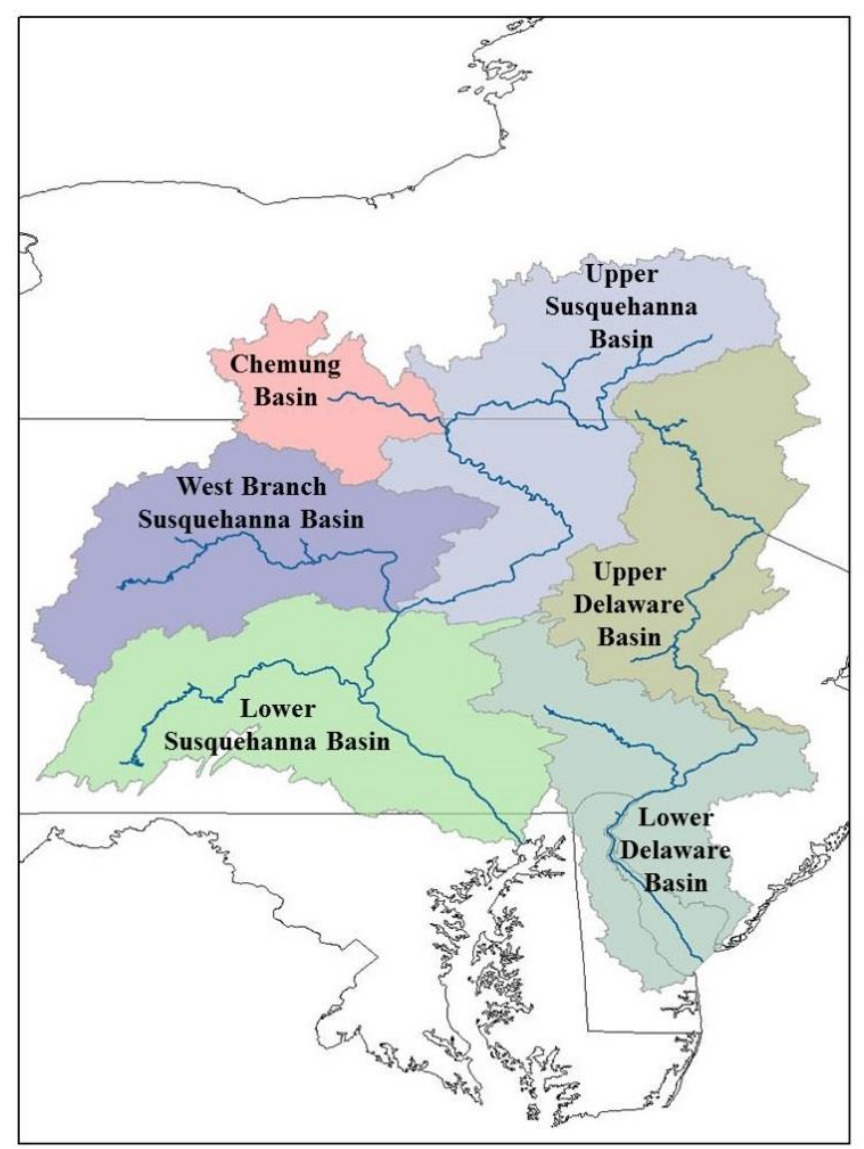

Figure 1. Graphical representation of the Susquehanna, Chemung, and Delaware River basins. Click image for an external version; this applies to all figures hereafter.

\section{Data and methods}

The Climate Forecast System (CFS) versions 1 and 2 (Saha et al. 2006, 2014) initial-hour analysis data and a climatology using the CFS Reanalysis (CFSR, Saha et al. 2010) from 1979-2010 were used to reconstruct the patterns and anomalies for both events on a $1^{\circ} \times 1^{\circ}$ grid. For the June 2006 event, the CFS version 1 initial-hour analysis was used, and the CFS version 2 was used for the September 2011 case. Two versions were used because no CFS version 2 data were available prior to April 2011. The SA method, as detailed by Hart and Grumm (2001), was used for each event. The SA was computed as

$$
S A=\frac{o-\mu}{\sigma}
$$

where $S A$ is expressed in standard deviations from normal, $O$ is the observed or forecast value from the CFS analysis, $\mu$ is the 21-day climatological running mean from the CFSR climatology, and $\sigma$ is the stan- dard deviation from the mean at each grid point. Parameters used in the SA computations included the PWAT, $u$ - and $v$-wind components, mean sea-level pressure (MSLP), and geopotential height.

The MARFC's observed and corrected multi-sensor precipitation estimates (Seo 1998; Lawrence et al. 2003) were used to show the spatial extent of both events. Gage point values were used to determine the maximum rainfall during each event, with gage point data obtained from the MARFC. These data points aided in showing the local maximum of heavy rainfall, which may not have been captured in gridded precipitation datasets.

To determine the characteristic of the frontal boundaries associated with both events, cross sections were taken normal to the main thickness gradient using 13-km Rapid Update Cycle (RUC; Benjamin et al. 2004) initial analysis, near-term, mesoscale model guidance mapped to $40-\mathrm{km}$ and valid during the time of heavy rain and flash flooding. Both events were archived at WFO BGM, which allowed easy product generation through use of the local office Weather Event Simulator (Magsig and Page 2002). The RUC was chosen based on local availability and because the model experienced only minimal changes from 2006 to 2011, which facilitated an accurate comparison of both events (COMET 2013). In addition, backward parcel trajectory analyses were calculated from the National Centers for Environmental Prediction Global Data Assimilation System using the NOAA Hybrid Single-Parcel Lagrangian Integrated Trajectory (HYSPLIT) model (Draxler and Hess 1997; model available at ready.arl.noaa.gov/HYSPLIT.php). These analyses also were completed for 1500-, 3000-, and 5000$\mathrm{m}$ AGL air parcels to determine if the air mass that produced heavy rainfall and flooding had tropical origins.

\section{Event overview}

\section{a. 26-28 June 2006}

The first flood event examined in this study occurred from 26-28 June 2006 across the mid-Atlantic region as a continuous supply of tropical moisture interacted with a nearly stationary cold front. Across the area, multiple river gage sites reached or exceeded major flood stage from Virginia north into central and eastern New York. In the northern mid-Atlantic specifically, significant flooding occurred when the mainstem Delaware and Susquehanna Rivers (Fig. 1) became inundated with excessive runoff from heavy 


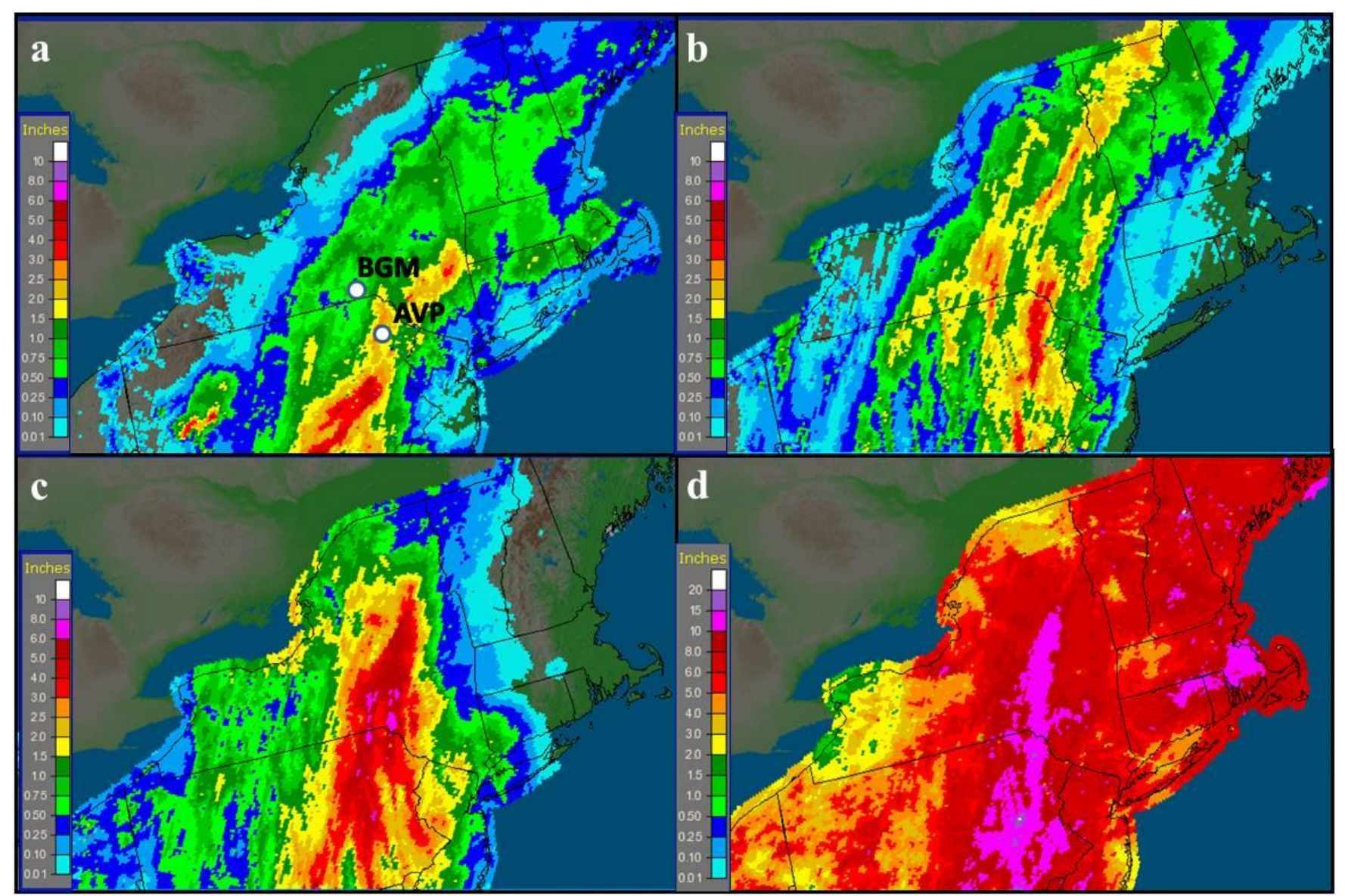

Figure 2. Observed multisensor precipitation estimates (in; multiply by $2.54 \mathrm{for} \mathrm{cm}$ ) for 24-h periods ending at (a) 1200 UTC 26 June 2006, (b) 1200 UTC 27 June 2006, and (c) 1200 UTC 28 June 2006. BGM and AVP in panel (a) represent approximate locations of both the Binghamton, NY, and Wilkes-Barre/Scranton, PA, metropolitan areas. Panel (d) shows total monthly multisensor observed precipitation estimates for June 2006.

rainfall over the 3-day period. In the week preceding heavy rainfall, much of the northern mid-Atlantic had been dry, with precipitation amounts generally $<1.27$ $\mathrm{cm}(0.50$ in) in central New York and northeastern Pennsylvania (Suro et al. 2009).

Heavy rain began across the northern mid-Atlantic as early as 26 June 2006, where 24-h amounts of $15.25-20.32 \mathrm{~cm}$ (6-8 in) were recorded across southcentral Pennsylvania, with localized amounts of 7.62$10.16 \mathrm{~cm} \mathrm{(3-4} \mathrm{in)} \mathrm{reported} \mathrm{as} \mathrm{far} \mathrm{north} \mathrm{at} \mathrm{the} \mathrm{Pocono}$ and Catskill Mountains (Fig. 2a). Successive rounds of heavy rain again fell across the region on 27 June 2006 , with additional amounts of 5.08-12.7 $\mathrm{cm} \mathrm{(2-5}$ in) recorded across portions of the Poconos and Catskill Mountains (Fig. 2b). By the evening of the 27th, multiple locations across central New York and northeastern Pennsylvania were already being impacted by flash flooding. The most widespread heavy rainfall occurred on the evening of 27 June 2006 into the morning of 28 June 2006, where additional totals of
7.6-12.7 cm (3-5 in) fell across central and eastern portions of the northern mid-Atlantic (Fig. 2c). By the end of the 3-day event, up to $38.1 \mathrm{~cm}$ (15 in) of rain had fallen across portions of northeastern Pennsylvania, with close to $35.6 \mathrm{~cm}$ (14 in) across the headwaters of the Delaware River in Delaware County, New York. As a result of the rainfall across the headwaters of the Delaware and Susquehanna River basins, record flooding was recorded downstream in the greater Binghamton, New York, metropolitan area, with major flooding observed further downstream in the greater Scranton/Wilkes-Barre area.

In addition to river flooding, the June 2006 flood event resulted in extensive flash flooding, with over 200 flash flood reports received across the entire midAtlantic. Flash flooding was directly responsible for the destruction of two Interstate- 88 bridges carrying northbound and southbound traffic over Carrs Creek near Unadilla, New York (NOAA 1995-2012). The catastrophic failure of the Interstate- 88 bridges alone 
resulted in two fatalities as drivers drove off the highway into raging floodwaters below. By the end of the event, over 275000 voluntary evacuations were ordered and over 1200 water rescues were performed in the state of Pennsylvania alone. The combined impacts of river and flash flooding resulted in damage estimates exceeding \$1B, along with 17 fatalities from Virginia to central New York (NOAA 1995-2012).

\section{b. 7-8 September 2011}

Five years later, another significant flood event occurred across portions of the mid-Atlantic region as the remnants of Tropical Storm Lee stalled over the lower Ohio River Valley in early September 2011. One week prior (26-29 August 2011), Hurricane Irene brought heavy rains and flooding to portions of Vermont, eastern New York, New Hampshire, and New Jersey (NWS 2012b). Although the heaviest rains occurred east of where heavy rains and flooding occurred with the Tropical Storm Lee event, heavy rains from Hurricane Irene still occurred across the headwater locations of both the Delaware and Susquehanna Rivers, where close to $12.7 \mathrm{~cm}$ (5 in) were recorded (Fig. 3a). As a result, soil conditions across much of the Catskills and Twin Tiers regions of central New York and northeastern Pennsylvania were near or at saturation (Fig. 3b) - as inferred from large precipitation departures from normal. The results were disastrous for portions of the mid-Atlantic, as heavy rains over a 4-day period from 6 to 10 September 2011 were combined with very moist antecedent conditions to produce widespread river flooding and flash flooding from Virginia north through central New York.

Heavy rains associated with the remnant Tropical Storm Lee circulation began during the early morning of 7 September 2011 across the northern mid-Atlantic. Periods of torrential rain, with rainfall rates of 5.08$7.68 \mathrm{~cm} \mathrm{~h}^{-1}\left(2-3 \mathrm{in} \mathrm{h}^{-1}\right)$ continued through much of the day, which quickly led to major river and flash flooding for portions of the Susquehanna Valley of both central Pennsylvania and central New York. Across the northern mid-Atlantic, numerous daily rainfall records were set, including $19.02 \mathrm{~cm}$ (7.49 in) at Binghamton, New York, and $19.58 \mathrm{~cm}$ (7.71 in) at Harrisburg, Pennsylvania. The heaviest rains fell in a $24-\mathrm{h}$ period from 7 to 8 September 2011, where 1-day storm total rainfall eclipsed $27.9 \mathrm{~cm}$ (11 in) just west of downtown Binghamton (Fig. 4), which surpassed the 500-yr average rainfall recurrence interval (DeGaetano and Zarrow 2011).

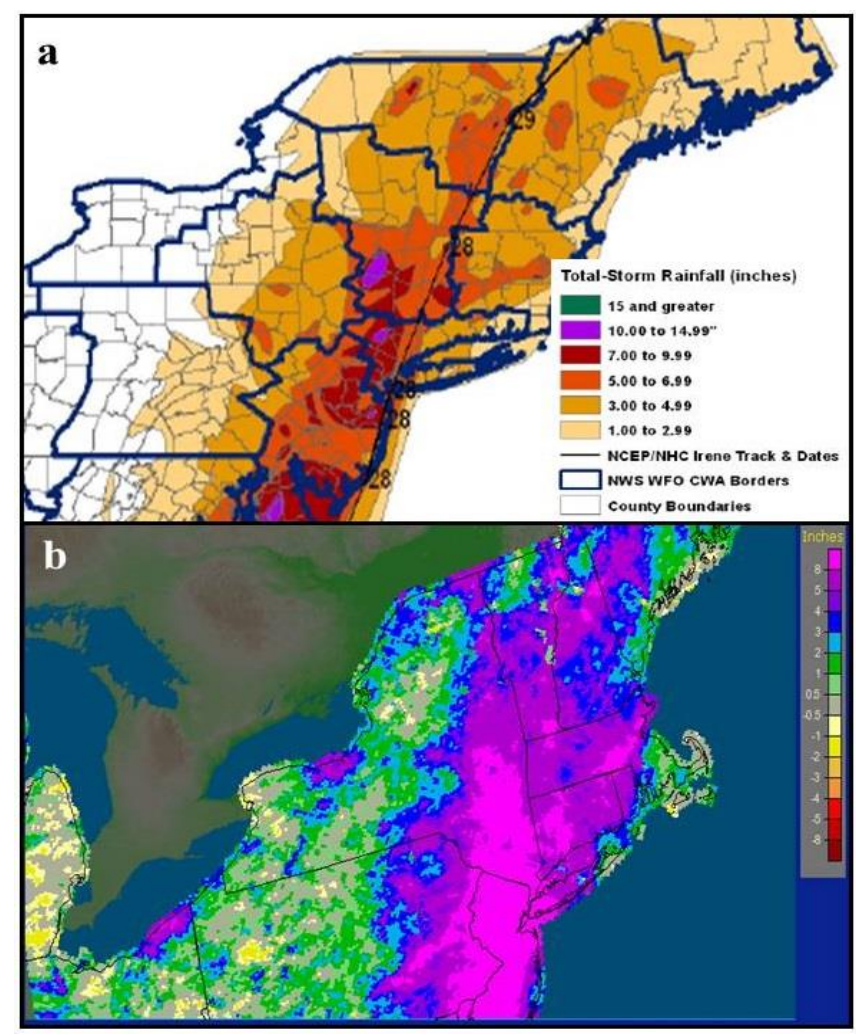

Figure 3. Panel (a) shows Hurricane Irene's observed storm total rainfall from 24-30 August 2011 (adapted from NWS 2012b); the thin black line represents the observed track from the National Hurricane Center. Panel (b) displays observed multisensor precipitation estimates (in, shaded; multiply by 2.54 for $\mathrm{cm}$ ) for August 2011 departures from normal.

As a result of extremely heavy rainfall, numerous record river stage levels set during the June 2006 flood were shattered along the mainstem Susquehanna River. The river stage of $13.00 \mathrm{~m}(42.66 \mathrm{ft})$ at WilkesBarre, Pennsylvania, surpassed the record level of $12.47 \mathrm{~m}(40.91 \mathrm{ft})$ set in 1972 by floodwaters from Hurricane Agnes; 11 other locations also recorded their highest river stage levels of all-time. By the event's end, close to 200 flash flood reports were received from Virginia north into central New York State. As with the June 2006 event, the flooding resulted in damage estimates again exceeding $\$ 1 \mathrm{~B}$, with 10 fatalities directly linked to flooding (NWS 2012c).

\section{Event evolution and comparison}

\section{a. June 2006}

At 1200 UTC 26 June 2006, an upper trough over western Ontario extended south through the western Great Lakes and Lower Mississippi River Valley (not 


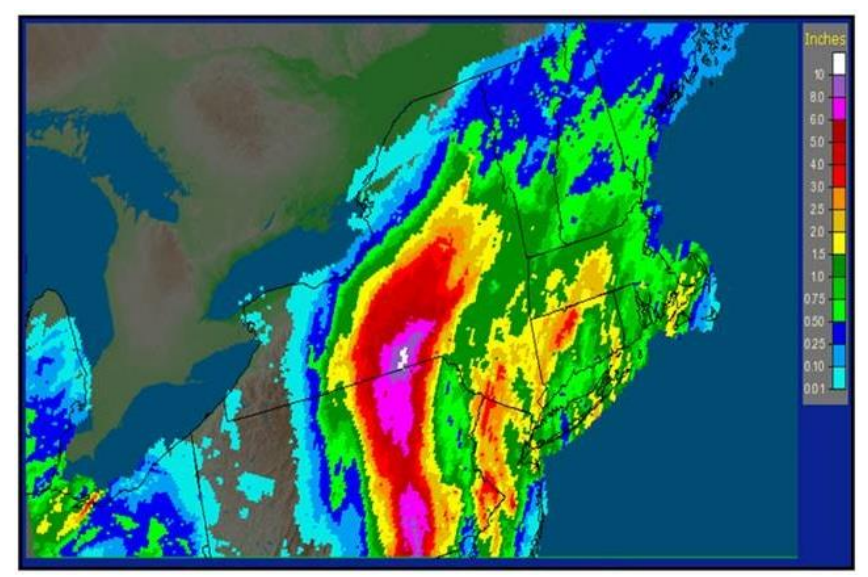

Figure 4. Observed multisensor precipitation estimates (in, shaded; multiply by 2.54 for $\mathrm{cm}$ ) for the 24 -h period ending 1200 UTC 8 September 2011.

shown). Through the duration of the 3-day event, this trough made little eastward progress as a blocking upper ridge prevailed across the western Atlantic. Broad southerly flow along the western periphery of the upper ridge, in conjunction with strengthening southerly flow in advance of the upper trough, combined to establish a continuous influx of tropical moisture along the East Coast, which persisted through the duration of the event. The presence of this feature supports findings by Dirmeyer and Kinter (2010) and Moore et al. (2012), who each showed that strong subtropical ridging across the western Atlantic can act to enhance tropical moisture advection into the mid-latitudes as the geopotential height gradient increases in response to an approaching long-wave trough to the west. The well-established tropical connection was evident in the NOAA/National Environmental Satellite, Data, and Information Service (NESDIS) blended total precipitable water (TPW; Kidder and Jones 2007) satellite image valid at 1800 UTC 27 June 2006 (Figs. 5a-b), which showed a tongue of tropical moisture extending north along the Eastern Seaboard. This narrow corridor of tropical moisture is consistent with the development of an atmospheric river (Zhu and Newell 1998; Ralph et al. 2005), which has been shown in previous studies to result in significant flash flooding if focused over a particular area for a long period of time (Ralph et al. 2004; Moore et al. 2012). The Weather Prediction Center's (WPC's) surface analysis valid at 0000 UTC 26 June 2006 (not shown) placed the main cold front associated with the upper trough from northeastern New York southward through the central Appalachians. The 0000 UTC 27 June 2006 WPC surface analysis (not shown) indicated the cold front had retro-

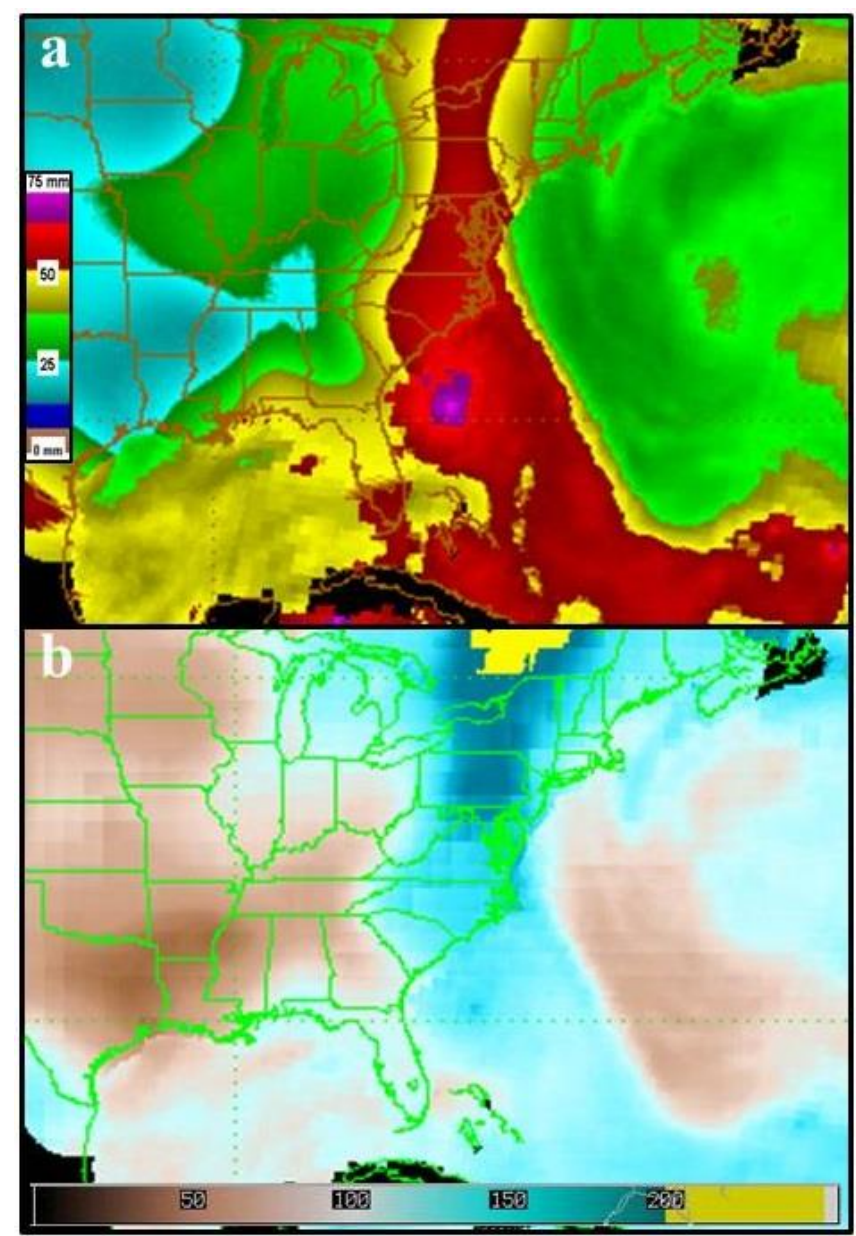

Figure 5. NOAA/NESDIS (a) blended TPW (mm) and (b) percent of normal TPW, both valid at 1800 UTC 27 June 2006.

graded in response to increasing southerly and southeasterly flow at $925-850 \mathrm{hPa}$, with no indications of any coastal frontal boundaries along the Eastern Seaboard at this time. During the early morning of 28 June 2006, a well-defined short-wave trough moved up the East Coast along the western periphery of the western Atlantic upper-level ridge (Fig. 6). The WPC surface analysis valid at 0000 UTC 28 June 2006 (Fig. 7) again showed the main synoptic boundary well west of western New York and western Pennsylvania, with a weak surface low analyzed across southeastern Virginia. This low continued to move northward through the night before reaching northern New Jersey by 1200 UTC (not shown), with heavy rain finally ending as the surface low moved towards New England.

\section{b. September 2011}

Tropical Storm Lee initially made landfall along the central Louisiana coast on 3 September 2011 


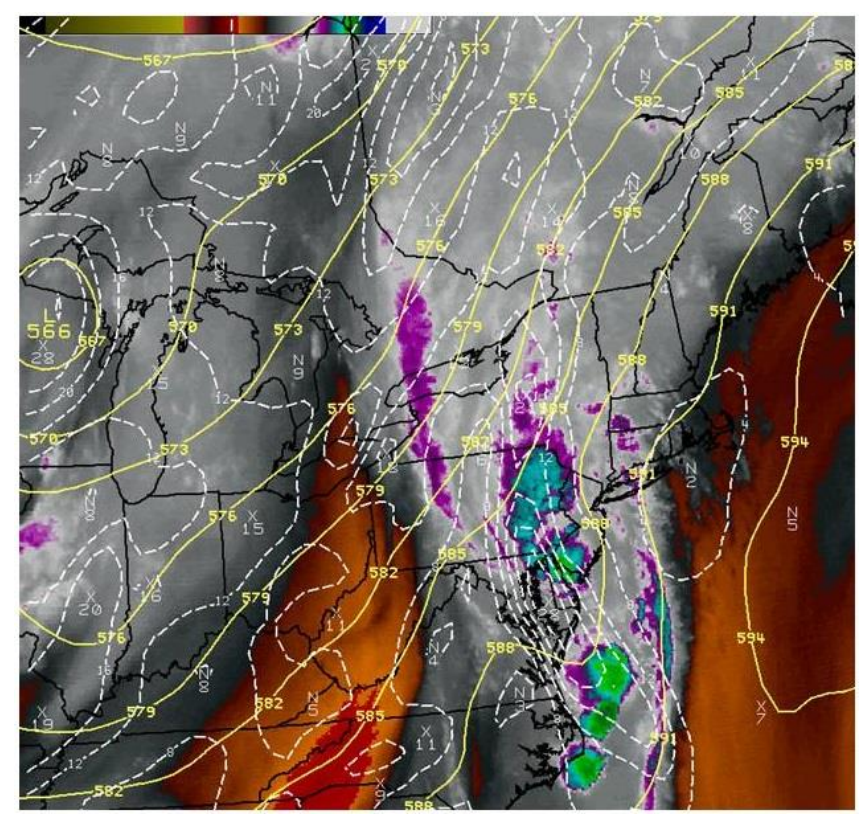

Figure 6. Water vapor image and RUC 0 -h $500-\mathrm{hPa}$ vorticity (white dashed lines, contoured every $4 \times 10^{-5} \mathrm{~s}^{-1}$ ) and geopotential height (yellow; contoured every 30 dam) valid 0600 UTC 28 June 2006.

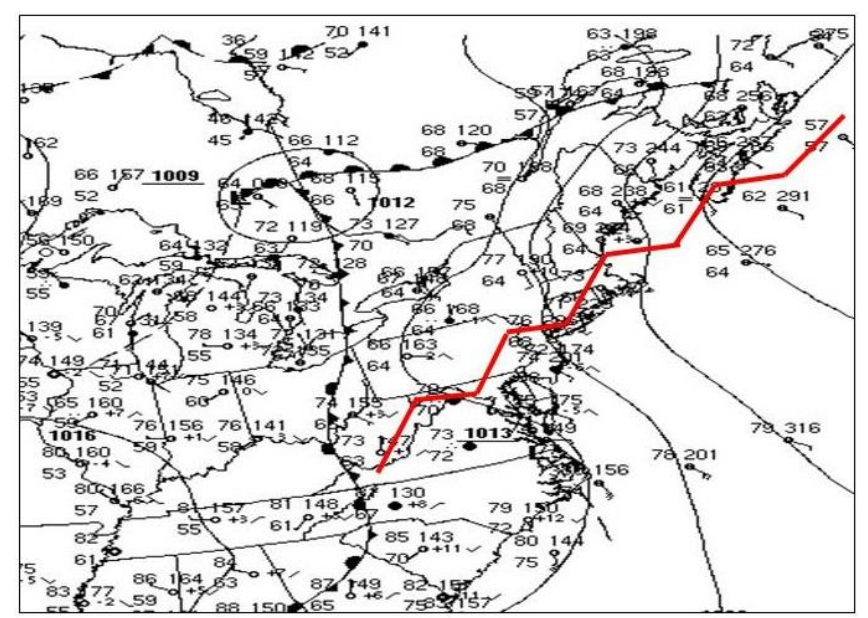

Figure 7. Surface analysis valid 0000 UTC 28 June 2006 with the approximate location of the inverted surface ridge axis (i.e., coldair damming signature) indicated by the thick, red, zigzag line. Image courtesy of WPC.

(Brown 2011). From this location, the tropical circulation meandered across the southeastern United States where it finally transitioned into an extratropical circulation before reaching northern Georgia on the morning of 6 September 2011 (not shown). Aloft, an upper trough continued to amplify southward across the Great Lakes and Ohio Valley, where it eventually consolidated with the remnant Lee circulation to form a closed low across the lower Ohio Valley by the morning of 7 September 2011 (not shown). Strengthening southerly flow ahead of the amplifying trough forced the northward movement of the low-level circulation towards the central Appalachians, with the remnant surface low located near eastern Tennessee on the morning of 7 September 2011 (Fig. 8). This low continued moving northward through the day before reaching southeastern Ohio by 0000 UTC 8 September 2011 (not shown). Meanwhile, well off the southeastern United States coast, Hurricane Katia began a northward turn towards Bermuda by the morning of 7 September 2011 as southerly flow strengthened across the eastern third of the United States and adjacent western Atlantic (not shown). As the day progressed, loops of blended TPW images showed a deep moisture plume originating over Hurricane Katia and moving northwest towards the northern mid-Atlantic (labeled 2 in Fig. 9a). This secondary moisture source acted as a catalyst for a second area of heavy rain and flash flooding across portions of southeastern New York, New Jersey, and Connecticut (Fig. 4).

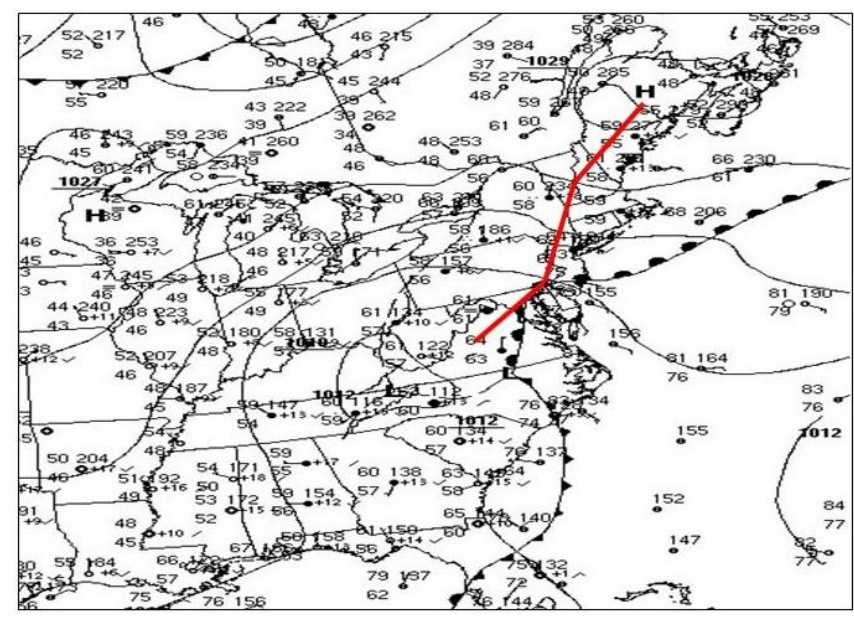

Figure 8. As in Fig. 7 but for 1200 UTC 7 September 2011.

\section{c. Synoptic pattern comparison}

Inspection of 500-hPa CFSR height anomalies revealed a pair of blocking, midlevel, high geopotential height centers over the northern Atlantic (Figs. $10 \mathrm{a}-\mathrm{b})$ for both cases, with heights $>1-3 \sigma$ above normal as each ridge center approached 594 dam. The strength of these ridges created a strong mid-latitude block that caused both upstream troughs over the central United States to exhibit little eastward movement in the days leading up to both events. Interestingly for the September 2011 event, the presence of Hurricane Katia south of Bermuda likely strengthened the upperridge center over the northern Atlantic as warm, asymmetric outflow from the hurricane interacted with a 


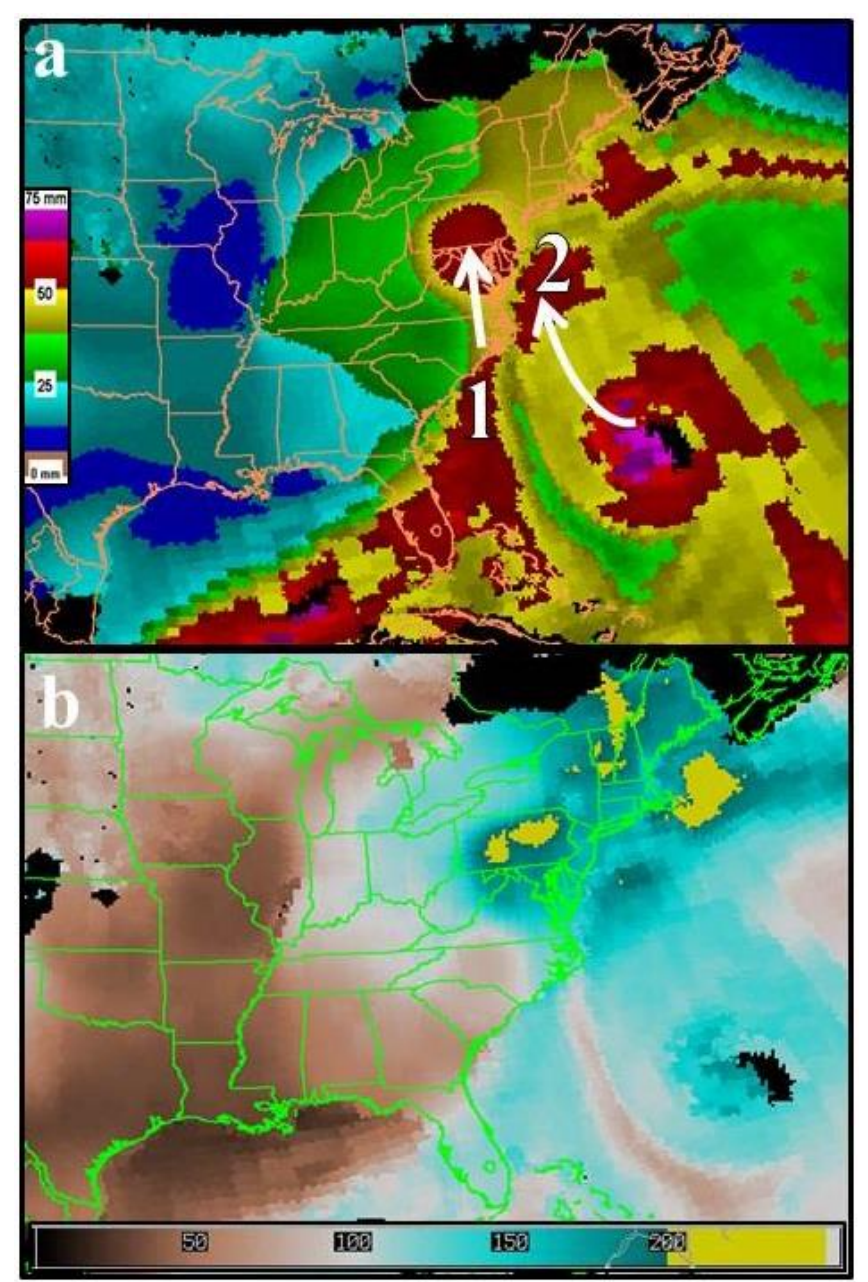

Figure 9. As in Fig. 5, but for 0027 UTC 8 September 2011. Numbers in (a) represent approximate locations of two separate tropical airstreams, with corresponding white arrows depicting overall movement prior to the image valid time.

developing potential vorticity gradient between the western Atlantic ridge and upstream trough (not shown; Jurewicz 2012). Strong blocking high-pressure centers, combined with the presence of deep upper troughs extending from the central Great Lakes into the Deep South, would allow both of the north Atlantic ridges to amplify with time. Along the top of the ridge, both events exhibited strong anticyclonically curved jet streaks with $u$ of 2-3 $\sigma$ above normal (Figs. 10c-d). Much of the northern mid-Atlantic region was under the right-entrance region of these jet streaks, which favored strong upper-level divergence over both areas of flooding (Fig. 11; Moore and VanKnowe 1992).

With an increasing height gradient, the $850-\mathrm{hPa} v-$ anomalies for both events quickly approached $2-3 \sigma$ above normal along the Eastern Seaboard (Figs. 12ab). In response to strengthening low-level flow, PWAT values also increased markedly as values approached $2-3 \sigma$ above normal (Figs. 12c-d). Interestingly for the June 2006 event, the low-level moisture plume (i.e., atmospheric river) could be traced back to the tropical Atlantic (Fig. 5a), whereas the tropical moisture source for the September 2011 event appeared to originate from both the eastern Gulf of Mexico and tropical Atlantic (Fig. 9a). Based on previous research by Stuart and Grumm (2009), both events would fall into the Gulf/tropical origins category as the main moisture plume for both cases was either rooted in the tropical Gulf of Mexico or southern Atlantic Ocean. Moreover, both events also could be classified as a synoptictropical event type based on earlier research by Grumm and Holmes (2007) that showed how flash flooding could become more devastating if an M79 synoptic-type flash flood setup interacts with deep tropical moisture from a remnant tropical circulation or atmospheric river with well-established tropical origins.

\section{d. Vertical motion forcing}

During the early morning of 28 June 2006, a weak, low-amplitude short-wave trough moved up the East Coast (Fig. 6). Manual surface analysis (Fig. 13) valid at 0900 UTC indicated a mesolow just east of Philadelphia with a coastal front extending north through northern New Jersey, southeastern New York, and into central New England. South of this boundary and near the mesolow, dewpoint temperatures were $18-21^{\circ} \mathrm{C}$ $\left(64-69^{\circ} \mathrm{F}\right)$, with $14-17^{\circ} \mathrm{C}\left(57-63^{\circ} \mathrm{F}\right)$ analyzed to its north and west. Also evident was an inverted surface ridge axis that extended west from the northern Atlantic into central New England and central New York (Figs. 7 and 13). The appearance of an inverted surface ridge axis with high pressure to the north was shown by Nielsen (1989) to be an identifiable pattern for cold-air damming and the development of coastal fronts in eastern New England.

Cross-sectional analyses taken from near Toronto, Ontario, southeast through the greater New York City metro area and using the 0 -h RUC analysis valid 0900 UTC 28 June 2006 revealed a synoptic-scale sloping region of midlevel frontogenesis (Figs. $14 \mathrm{a}-\mathrm{b}$ ) from near Binghamton, New York, northwest through southern Ontario. Along the midlevel feature, upward motion (Fig. 14a) was maximized across the southern tier of New York State as the ascending branch of a frontogenetically produced direct thermal circulation combined with the release of convective instability 


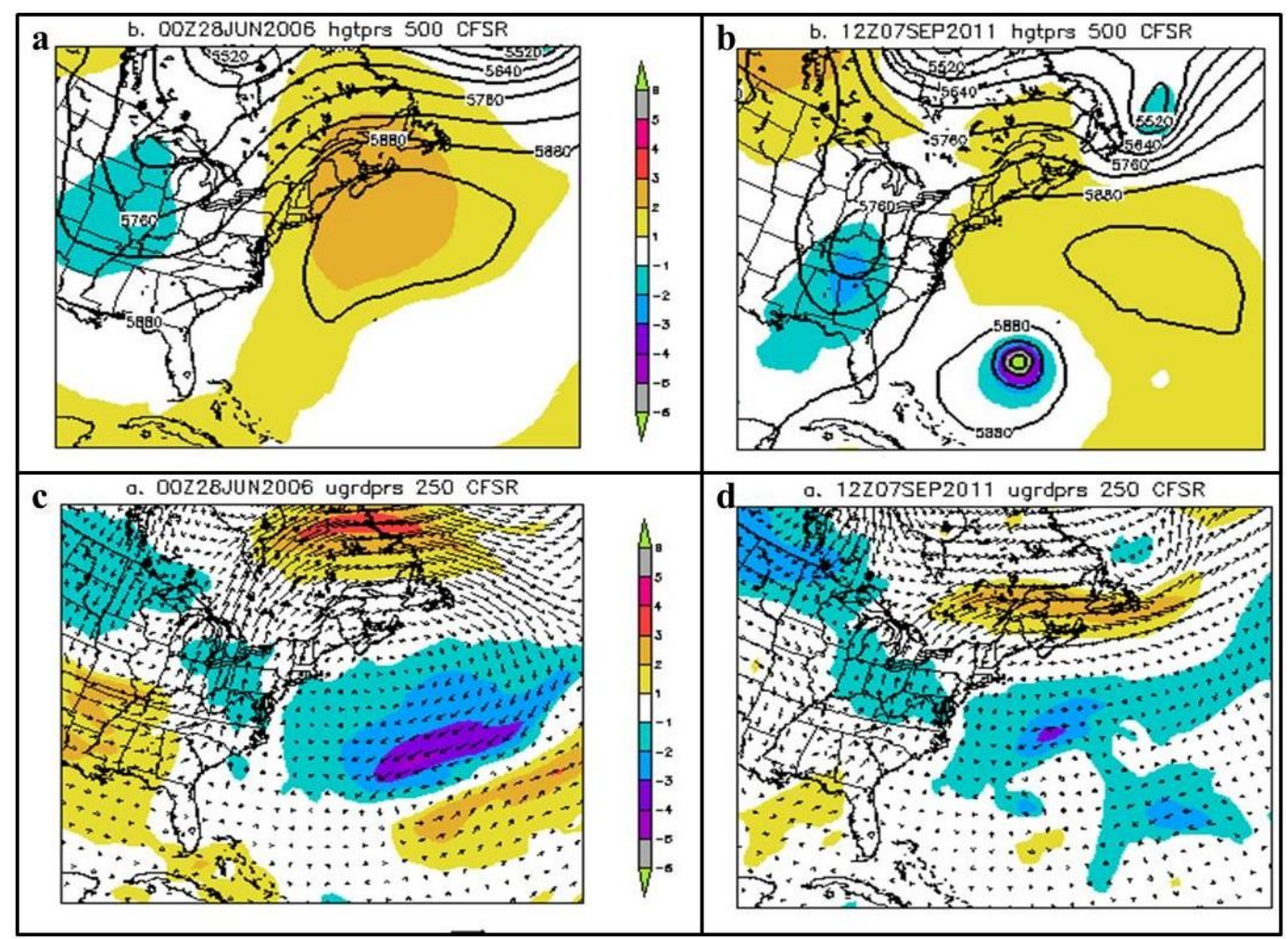

Figure 10. CFSR 500-hPa height anomalies for (a) 0000 UTC 28 June 2006 and (b) 1200 UTC 7 September 2011; and 250-hPa $u$-anomalies for (c) 0000 UTC 28 June 2006 and (d) 1200 UTC 7 September 2011.

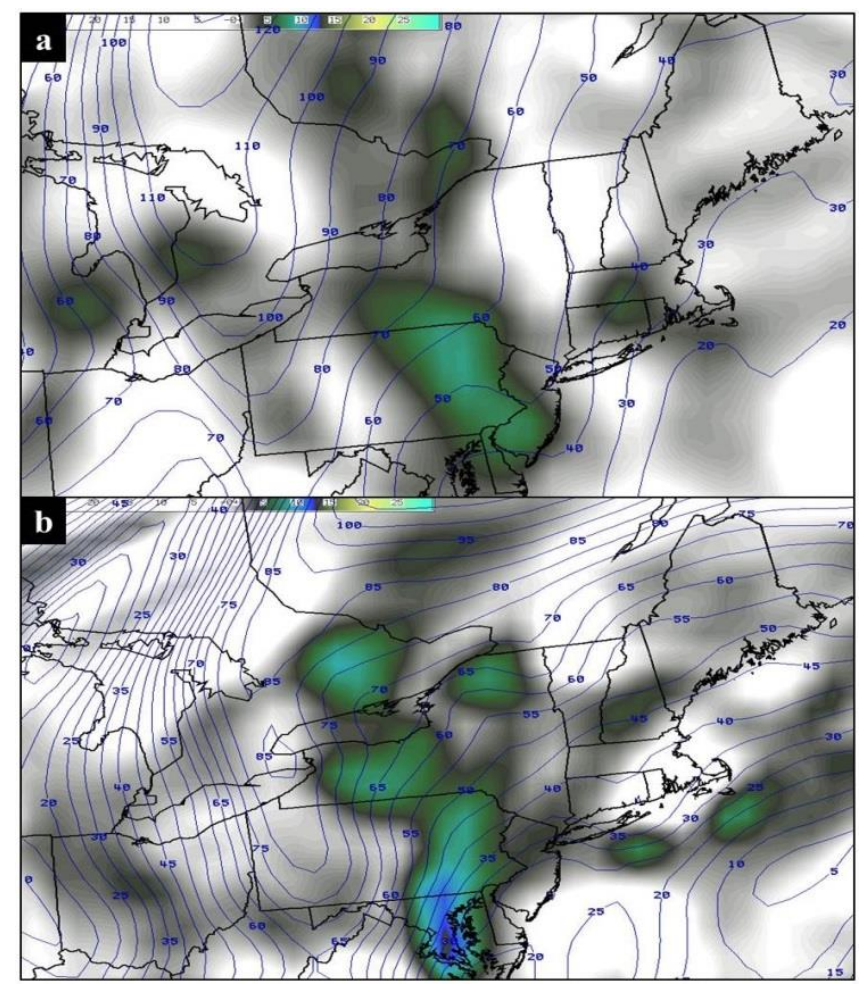

Figure 11. RUC 0-h analysis of 250-hPa wind speed (kt; multiply by 0.5144 for $\left.\mathrm{m} \mathrm{s}^{-1}\right)$ and divergence $\left(1 \times 10^{-5} \mathrm{~s}^{-1}\right.$; shaded $)$ valid at (a) 0600 UTC 28 June 2006 and (b) 0300 UTC 8 September 2011.
(Fig. 14b) in a region of broad, midlevel, warm-air advection (Fig. 15a). Low-level frontogenesis associated with the coastal boundary was apparent on both cross sections as a thin layer of frontogenesis just northwest of New York City, with a secondary region of ascent noted above the coastal front. Convectively unstable air, characterized by negative $\theta_{e}$ lapse rates (Fig. 15b), streamed northwestward into the northern mid-Atlantic region. The unstable air became juxtaposed with the midlevel frontogenesis (Fig. 15c), which resulted in a narrow and intense area of upward motion (Fig. 15b). Mosaic radar images (Fig. 15d) valid 0600 UTC 28 June displayed a region of unbroken reflectivity oriented in the along-flow direction, which - combined with the presence of an LLJ-is consistent with slabular layer lifting as discussed by James et al. (2005).

A manual surface analysis valid at 0300 UTC 8 September 2011 revealed another mesolow just south of Washington, DC, with a coastal front extending north through central Maryland, southeastern Pennsylvania, and central New Jersey (Fig. 16). The front then extended off the central New Jersey coast to a position just south of Long Island. Dewpoints south of the front were $22-25^{\circ} \mathrm{C}\left(71-77^{\circ} \mathrm{F}\right)$, with $16-17^{\circ} \mathrm{C}\left(61-63^{\circ} \mathrm{F}\right)$ 


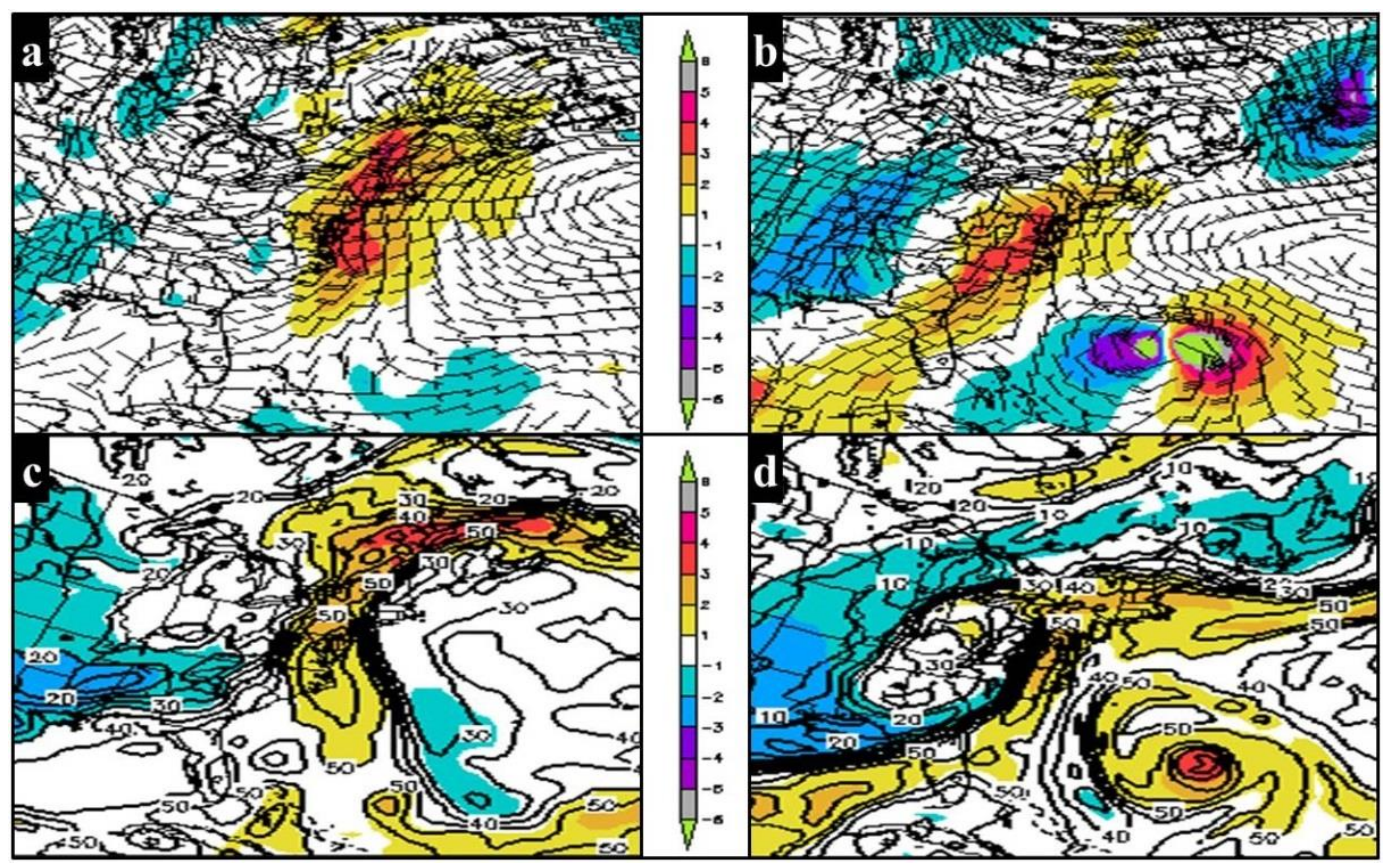

Figure 12. As in Fig. 10 but for 850-hPa $v$-anomalies valid at (a) 0000 UTC 28 June 2006 and (b) 1200 UTC 7 September 2011. The lower two panels are 1000-hPa PWAT anomalies valid at (c) 0000 UTC 28 June 2006 and (d) 1200 UTC 7 September 2011.

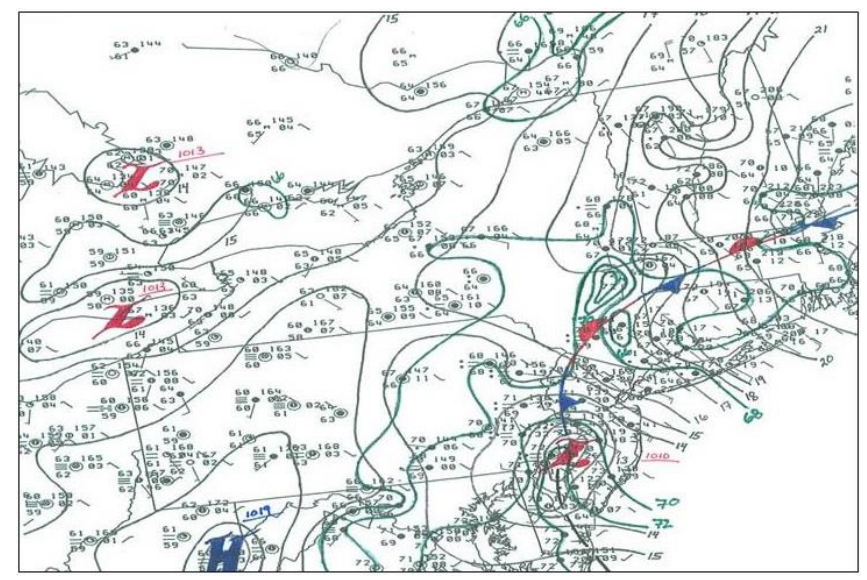

Figure 13. Manual surface analysis valid at 0900 UTC 28 June 2006. Both station data and surface fronts are analyzed using standard symbols. Solid black lines represent isobars in 1-hPa intervals with thick dashed lines representing surface troughs. Isodrosotherms drawn with solid green lines at $1.1^{\circ} \mathrm{C}\left(2^{\circ} \mathrm{F}\right)$ intervals for values $\geq 18.8^{\circ} \mathrm{C}\left(66^{\circ} \mathrm{F}\right)$.

immediately to its north, while a pressure ridge extended from the Canadian Maritimes southwest toward the mid-Atlantic region (Fig. 8).

A cross section taken from the 0300 UTC RUC analysis from near Toronto southeast through the greater New York City area again showed two distinct regions of upward motion (Fig. 17a); the first was associated with the coastal boundary analyzed in Fig. 16 , and the second directly linked to another syn-
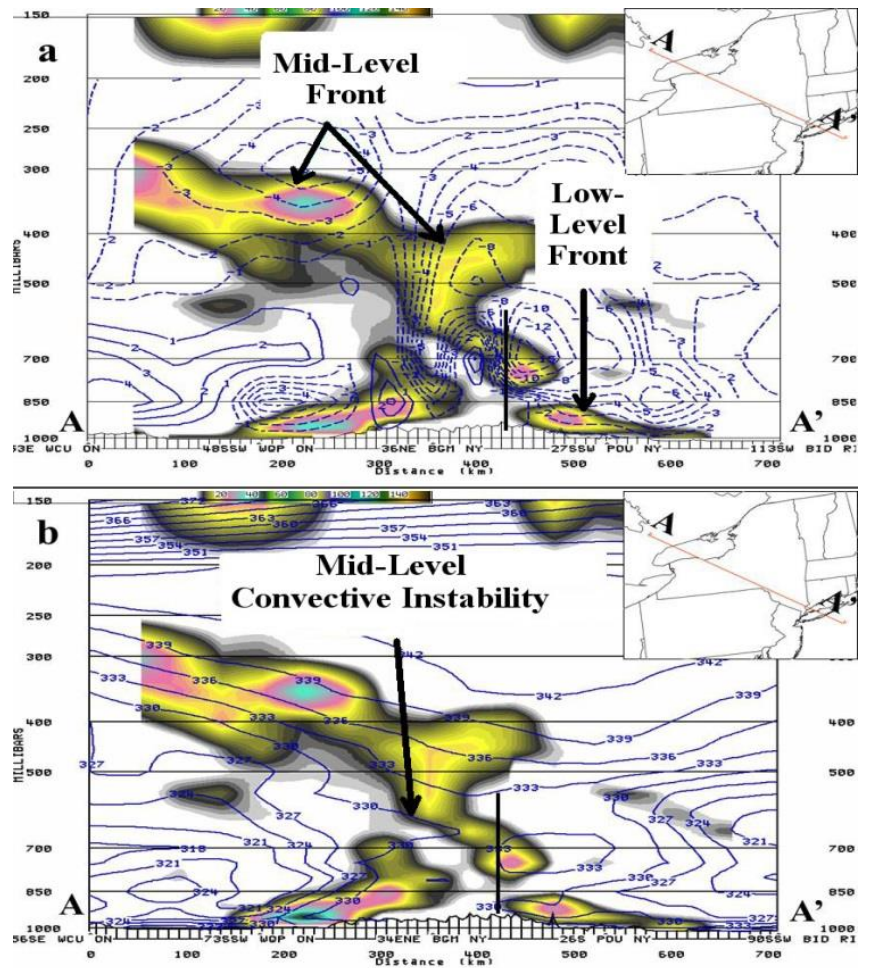

Figure 14. (a) RUC 0-h cross section of 2D Petterssen frontogenesis [shaded, $\mathrm{K}(100 \mathrm{~km})^{-1}(3 \mathrm{~h})^{-1}$ ] with vertical motion (contoured blue; $\mu \mathrm{b} \mathrm{s}^{-1}$ ) and (b) $\theta_{e}$ (contoured blue every $3^{\circ} \mathrm{C}$ ) with $2 \mathrm{D}$ Petterssen frontogenesis [shaded, $\mathrm{K}(100 \mathrm{~km})^{-1}(3 \mathrm{~h})^{-1}$ ] valid 0900 UTC 28 June 2006. Black vertical line on both figures represents approximate location of heavy rainfall axis. Cross section orientation shown in upper right corner of both images. 


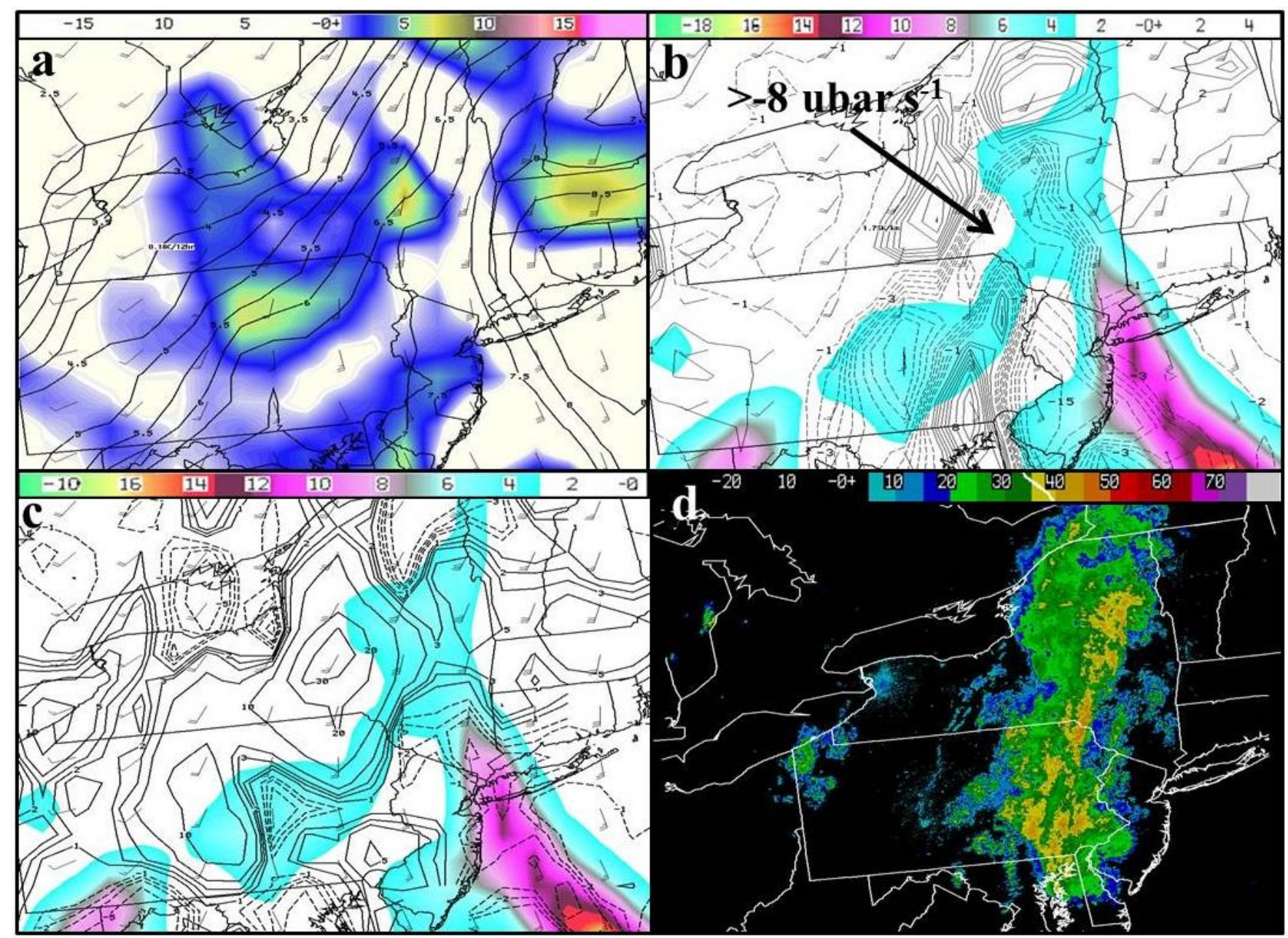

Figure 15. 0600 UTC RUC 0 -h analysis of (a) 700-hPa temperature advection [values $>0{ }^{\circ} \mathrm{C}(12 \mathrm{~h})^{-1}$ shaded], temperature $\left({ }^{\circ} \mathrm{C}\right.$, black contours), and wind barbs (kt, black); (b) 700-hPa $\theta_{e}$ lapse rate (values $\leq-3 \mathrm{~K} \mathrm{~km}^{-1}$ shaded) and wind barbs (kt, black), with $850-700-\mathrm{hPa}$ vertical motion ( $\mathrm{hb} \mathrm{s}^{-1}$; black contours); (c) 700-hPa 2D Petterssen frontogenesis $\left[\mathrm{K}(100 \mathrm{~km})^{-1}(3 \mathrm{~h})^{-1}\right]$, wind barbs (kt, black), and 700$\mathrm{hPa} \theta_{e}$ lapse rate (values $\leq-3 \mathrm{~K} \mathrm{~km}^{-1}$ shaded); and (d) $0600 \mathrm{UTC}$ regional radar reflectivity mosaic (dBZ).

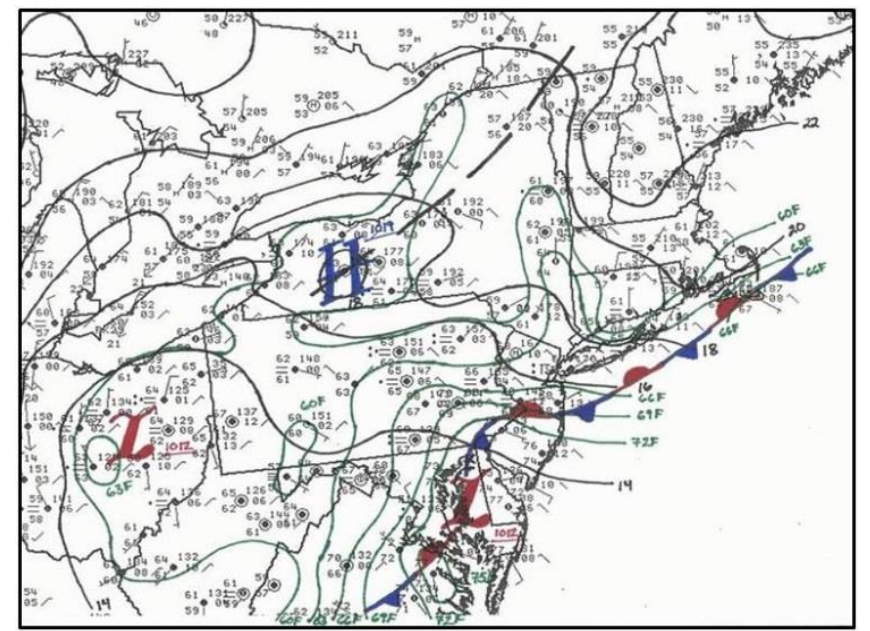

Figure 16. As in Fig. 13, but valid 0300 UTC 8 September 2011 using a 2 -hPa contour interval for pressure and a $1.7^{\circ} \mathrm{C}\left(3^{\circ} \mathrm{F}\right)$ contour interval for dewpoints $\geq 15.6\left(60^{\circ} \mathrm{F}\right)$. optic-scale midlevel front that extended from near Binghamton northwestward through southern Ontario. Similar to June 2006, a region of convective instability was present near the main midlevel synoptic front (Fig. 17b) in a region of well-established warm-air advection (Fig. 18a). This area of midlevel instability also appeared to stream northward into the northern mid-Atlantic region during the period of heavy rainfall (Fig. 18b), likely in association with a well-established LLJ as shown in Fig. 12. This instability, combined with strong midlevel frontogenesis (Fig. 18c), again resulted in a narrow and intense region of upward motion (Fig. 18b) that produced very heavy rainfall from the southern tier of New York State south into central and eastern portions of Pennsylvania. The regional radar mosaic valid at 0300 UTC (Fig. 18d) again showed a continuous region of reflectivity ori- 


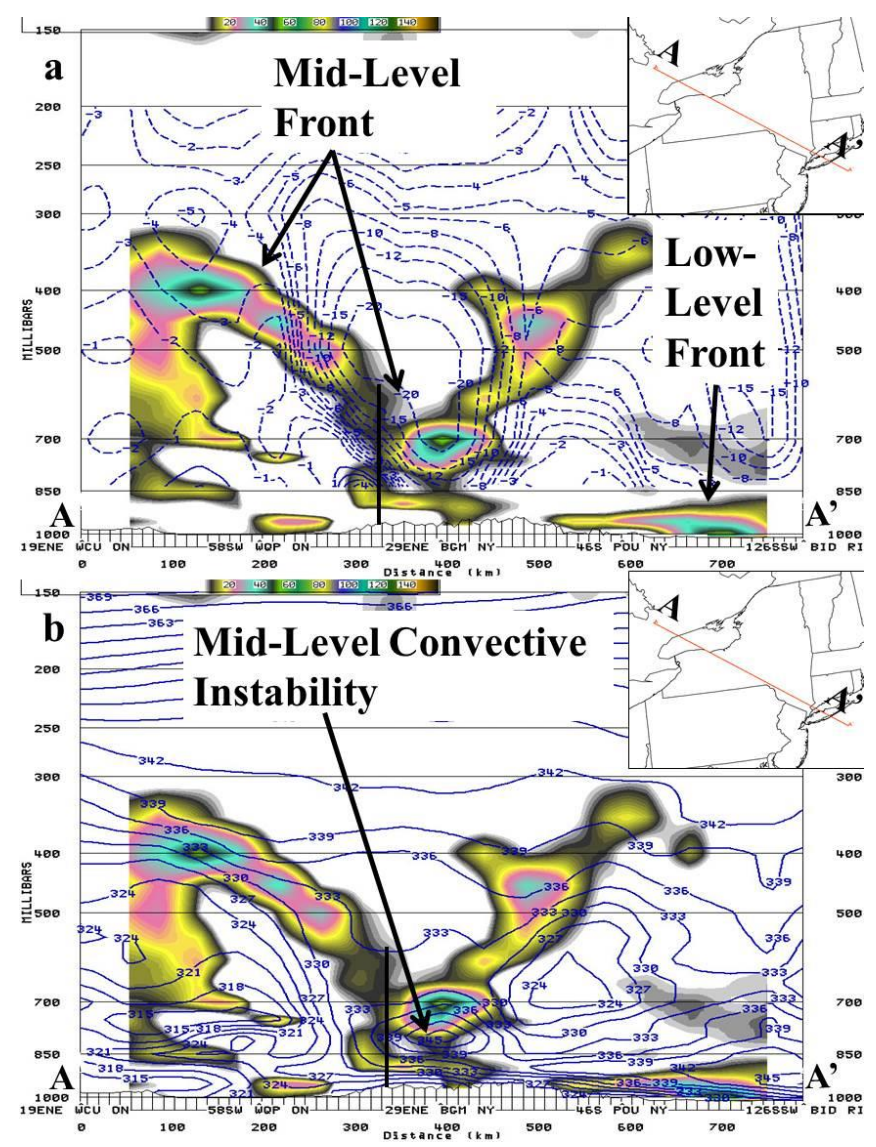

Figure 17. As in Fig. 14 but valid 0300 UTC 8 September 2011.

ented in the along-flow pattern, which is consistent with slabular-type lifting.

In summary, both the June 2006 and September 2011 flood events were characterized by blocking upper-level patterns that allowed a continuous supply of deep tropical moisture to advect northward into the northern mid-Atlantic. Favorable positioning under the right-entrance region of anticyclonically curved jetstreaks allowed broad upper-level divergence over the flood regions. Additionally, both events had midlevel, synoptic-scale frontal boundaries west of the flood regions. Ascent arising from the frontogenetically produced direct thermal circulations, combined with the presence of convectively unstable air masses, led to narrow, but intense, regions of upward motion that culminated in long-duration, heavy rainfall across the northern mid-Atlantic during both events.

\section{Discussion on possible role of coastal fronts}

An intriguing aspect of both cases was the presence of a coastal front extending poleward from a mesolow positioned near the Delmarva Peninsula. Both coastal fronts may have developed as a result of a strengthening thermal gradient arising from cold-air damming east of the Appalachians and strong onshore flow from the western Atlantic. This type of coastal front development was deemed Type-C coastal frontogenesis by Nielsen (1989). As a notable example of Type-C development and heavy rainfall production, Bosart and Dean (1991) showed how a coastal front with Type-C characteristics led to additional forcing for ascent from eastern Virginia north through eastern Pennsylvania during the historic Hurricane Agnes flood event of 1972. Other studies have shown additional cases where coastal fronts that were directly tied to tropical circulations provided the focus for localized heavy rainfall (Atallah and Bosart 2003; Colle 2003). In the cases shown in this paper, however, the coastal fronts did not appear to be directly tied to a tropical circulation.

Backward parcel trajectory analyses calculated for 1500-, 3000-, and 5000-m AGL air parcels ending at WFO BGM at 1200 UTC (Fig. 19a) showed that lowlevel and midlevel air parcels over the Binghamton region on the morning of 28 June 2006 originated in the tropics. The 1500-m air-parcel trajectory (red parcel trace in Fig. 19b) in particular indicated low-level air parcels ascended the coastal frontal zone en route to the Binghamton area during the morning of 28 June 2006. Similar to June 2006, 1500-m HYSPLIT backward parcel trajectory analysis ending at WFO BGM valid at 1200 UTC 8 September 2011 (red parcel trace in Figs. 20a-b) again showed that low-level parcels first began their ascent upon encountering the coastal front, with further ascent occurring as they became entrained in the midlevel synoptic-scale front west of the flood region. This corresponds well with the large upward motion maxima displayed in cross sections for both cases (Figs. 14a and 17a). The appearance of coastal fronts for both events suggests that air parcels arriving from the western Atlantic experienced both synoptic and mesoscale contributions for upward motion that culminated in extremely heavy rainfall and widespread flooding for northern portions of the midAtlantic. Specifically, for the September 2011 case, the coastal front appeared to be completely independent of the remnant tropical circulation, which is verified by both WPC (Fig. 8) and subjective manual surface analysis (Fig. 16). The presence of the coastal front, along with an influx of deep tropical moisture from Hurricane Katia, is thought to have combined to produce the secondary region of heavy rain and flooding from northern New Jersey northeast through western Connecticut. The June 2006 case did not present a 


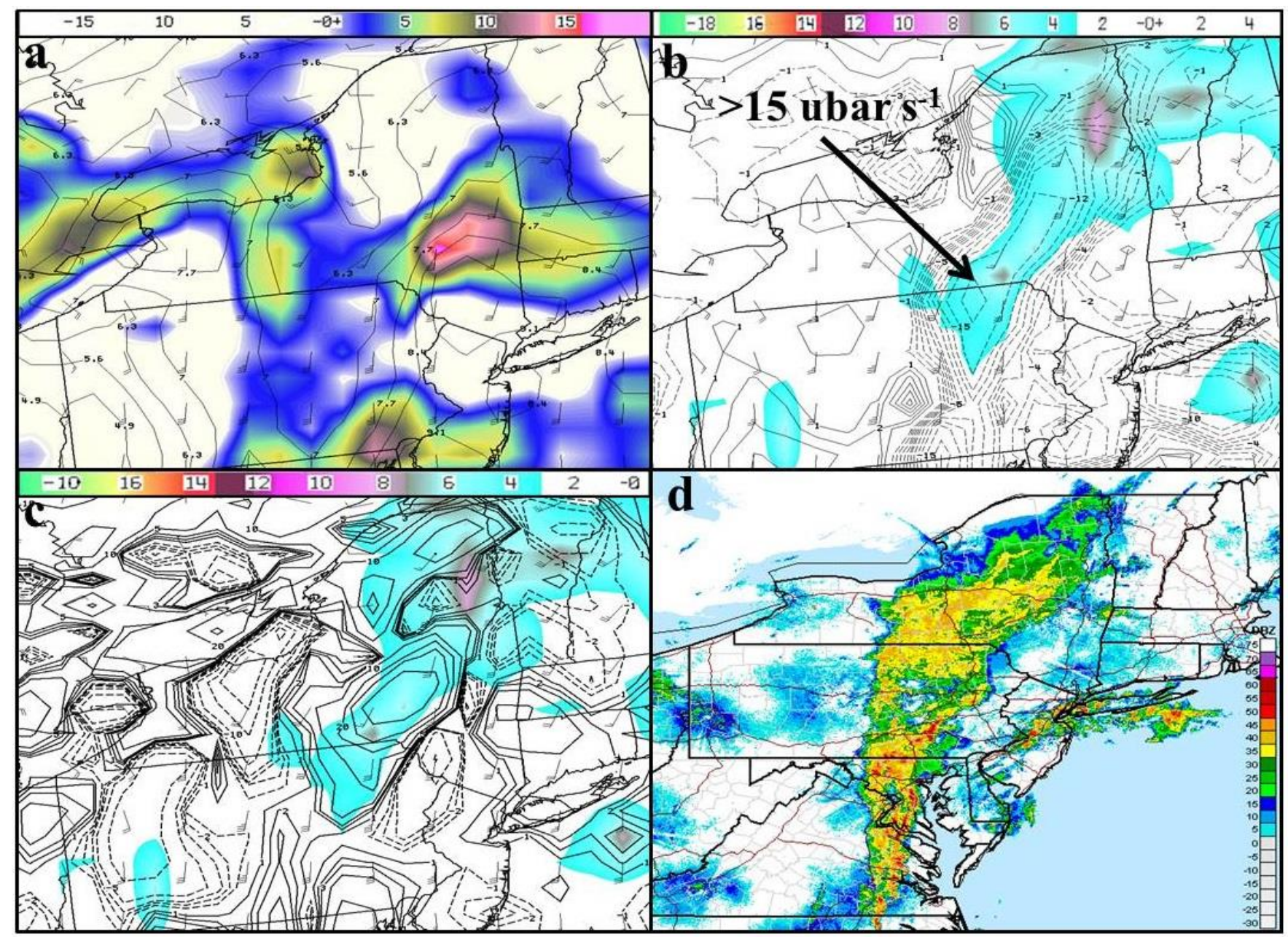

Figure 18. As in Fig. 15 but for valid 0300 UTC 8 September 2011.

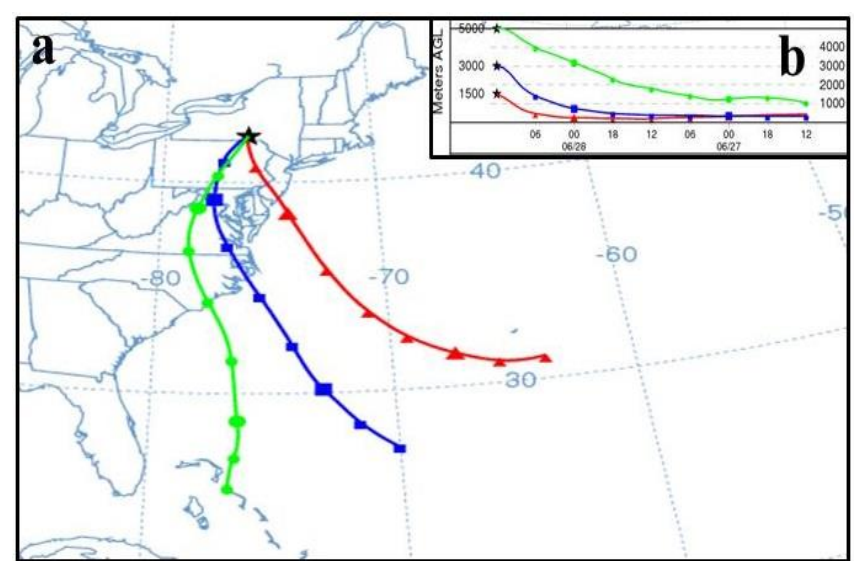

Figure 19. Backward air-parcel trajectory analysis for (a) $1500-\mathrm{m}$ (red), 3000-m (blue), and 5000-m (green) air parcels ending at Binghamton, NY, at 1200 UTC 28 June 2006 using the HYSPLIT model. Tick marks along each parcel path represent 6-h increments during the 48-h analysis period. Panel (b) is a time series of 1500m, 3000-m, and 5000-m air-parcel heights (AGL) along each individual parcel path. secondary precipitation maximum closer to the coast, which likely resulted from an overall lack of deep tropical moisture interacting with the coastal boundary as evidenced by drier air located directly offshore (Fig. 5a).

With much of the previous literature discussing a coastal front's influence on heavy rain and flooding confined to extratropical-transitioning hurricanes or wintertime precipitation scenarios, the events of June 2006 and September 2011 offer a unique mesoscale situation that potentially can be utilized as a patternrecognition tool for detecting future setups conducive to heavy rain and possible flooding. However, determining the true forcing contribution of the coastal front would require a separate modeling study, which is beyond the scope of this paper. Such a study would be able to determine whether upstream convection southeast of where the heaviest rains fell in the September 2011 event actually enhanced or reduced the 


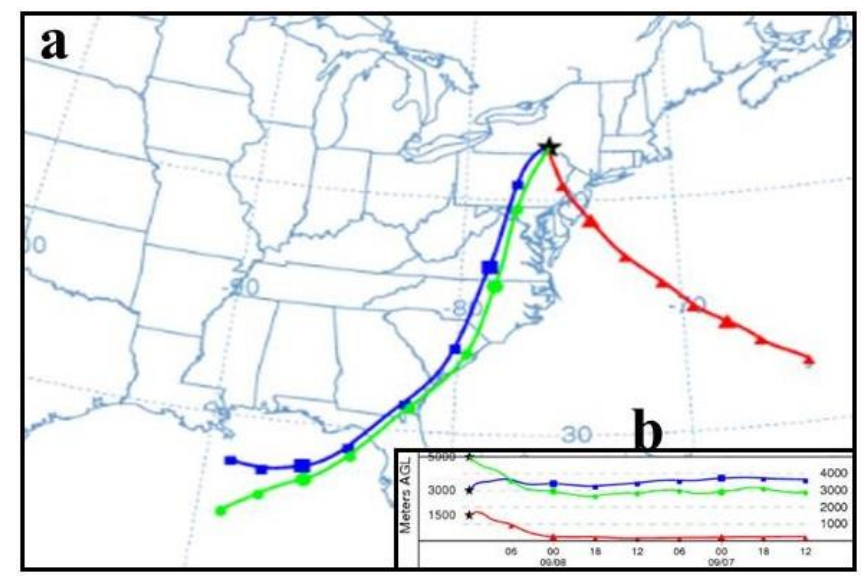

Figure 20. As in Fig. 19 but valid 1200 UTC 8 September 2011.

amount of rainfall that occurred across the central New York and Pennsylvania areas. For example, Mahoney and Lackmann (2007) discussed the effects of upstream convection on model quantitative precipitation forecast biases across the southeastern United States. The authors presented a case in which the operational models underforecasted the precipitation in a situation where the wind aloft was fairly weak, a front possessed anafront characteristics, and the area was under the influence of the right-entrance region of an upperlevel jet streak. The authors' hypothesis is that during these "slow convection" type events, low-level moisture advection is enhanced as latent heat release increases the low-level wind field towards an area of developing precipitation. Considering that the heaviest rainfall during the September 2011 event was well downstream of where the secondary precipitation maximum occurred, latent heat release may have indeed increased moisture advection into both the central New York and Pennsylvania regions. As discussed above, however, efforts to determine the true effects of the coastal front would require additional research to quantify whether the coastal fronts actually enhanced or decreased precipitation downstream across the Susquehanna and Delaware River basins.

\section{Conclusion}

The flood events of June 2006 and September 2011 were nothing short of historic for many locations throughout the northern mid-Atlantic area. Though the September 2011 event was of shorter duration (roughly $24 \mathrm{~h}$ ) as compared to the $>3$ day June 2006 heavy rainfall event, 24-h rainfall totals $>27.9 \mathrm{~cm}$ (11 in) for the September 2011 case caused unprecedented flooding for the greater Binghamton metropolitan area and numerous other locations along the Susquehanna River in both New York and Pennsylvania. In the Binghamton area alone, three river gage sites along the Susquehanna River recorded their all-time highest river levels, with the combined impacts of both river and flash flooding resulting in damage estimates totaling over $\$ 900 \mathrm{M}$ in Broome and Tioga Counties (NWS 2012c). At the conclusion of both events, over 20 fatalities could be attributed to floodwaters resulting from periods of heavy rainfall and flash flooding.

This analysis has shown that the two cases displayed many similarities. For both cases, a strong, blocking upper-level ridge was present across the north Atlantic with a deep upper trough across the American Deep South. As a result of the nearly stagnant upper-level pattern, both events also had well-established atmospheric rivers in place that allowed for a continuous supply of deep tropical moisture north into the regions of flooding. Of particular interest was the contribution of forcing on both the synoptic-scale and mesoscale during the course of heavy rainfall. For both events, strong synoptic forcing was supplied by a midlevel front west of the flood regions, with additional forcing supplied on the mesoscale as westward-moving air parcels ascended coastal boundaries that were present along the Eastern Seaboard during both events. While the overall coastal fronts' contributions on heavy rainfall production can be debated, the presence of such boundaries suggests the East Coast can be subjected to flood patterns that have not been documented in previous literature.

From an operational perspective, the documented cases can be used by forecasters to detect similar synoptic and mesoscale setups that may be conducive to high precipitation efficiency and possible flooding. The ability to use standardized anomalies to detect anomalously strong blocking patterns can serve as a signal that strong moisture advection may occur over a particular location. In addition, real-time remotesensing tools, such as the blended TPW satellite product, can give forecasters a more representative picture of the moisture content through a greater depth of the atmospheric column. And, finally, the use of cross sections with traditional plan-view images of frontogenesis, upward motion, and $\theta_{e}$ lapse rates can help isolate locations where precipitation efficiency and heavy rainfall production may be maximized. The early recognition of similar setups will assist the NWS in its attempt to build a weather-ready nation by ensuring that notification of expected hazards are presented well before a significant heavy rainfall event 
gets underway. Early dissemination of such hazards to decision makers and key emergency response personnel will help minimize losses of both life and property.

Acknowledgments. The authors express their sincere appreciation to both Neil Stuart of the Albany, New York, WFO and Michael Jurewicz of WFO BGM for their many insightful discussions on the topic of East Coast flood events and possible coastal-front interactions. Additional gratitude is extended to James Brewster of WFO BGM for assistance in developing Fig. 1, as well as to Sheldon Kusselson of NOAA/NESDIS for supplying archived blended TPW and percent of normal satellite graphics for the June 2006 flood event. We also thank Brian Miretzky, Dr. Dave Radell, and Laurie Hogan of NWS Eastern Region Headquarters for their thorough review of the original manuscript. And, finally, sincere appreciation is extended to Dr. Russ Schumacher of Colorado State University and one anonymous reviewer whose comments and suggestions greatly improved the overall quality of the final manuscript.

\section{REFERENCES}

Atallah, E. H., and L. F. Bosart, 2003: The extratropical transition and precipitation distribution of Hurricane Floyd (1999). Mon. Wea. Rev., 131, 1063-1081, CrossRef.

Bell, G. D., and L. F. Bosart, 1988: Appalachian cold-air damming. Mon. Wea. Rev., 116, 137-161, CrossRef.

Benjamin, S. G., and Coauthors, 2004: An hourly assimilation-forecast cycle: The RUC. Mon. Wea. Rev., 132, 495-518, CrossRef.

Bosart, L. F., 1984: The Texas coastal rainstorm of 17-21 September 1979: An example of synoptic-mesoscale interaction. Mon. Wea. Rev., 112, 1108-1133, CrossRef.

, and D. B. Dean, 1991: The Agnes rainstorm of June 1972: Surface feature evolution culminating in inland storm redevelopment. Wea. Forecasting, 6, 515-537, CrossRef.

, C. J. Vaudo, and J. H. Helsdon Jr., 1972: Coastal frontogenesis. J. Appl. Meteor., 11, 1236-1258, CrossRef.

Brown, D. P., 2011: Tropical cyclone report: Tropical Storm Lee (AL132011) 2-5 September 2011. Tech. Rep., National Hurricane Center, National Oceanic and Atmospheric Administration, 35 pp. [Available online at www.nhc.noaa.gov/data/tcr/AL132011_Lee.pdf.]

Colle, B. A., 2003: Numerical simulations of the extratropical transition of Floyd (1999): Structural evolution and responsible mechanisms for the heavy rainfall over the northeast United States. Mon. Wea. Rev., 131, 2905-2926, $\underline{\text { CrossRef. }}$
COMET, cited 2013: Operational models matrix: Characteristics of NWP and related forecast models. [Available online at www.meted.ucar.edu/nwp/pcu2/.]

Davis, R. S., 2001: Flash flood forecast and detection methods. Severe Convective Storms, Meteor. Monogr., No. 50, Amer. Meteor. Soc., 481-525, CrossRef.

DeGaetano, A., and D. Zarrow, 2011: Extreme precipitation in New York \& New England. Technical Documentation and User Manual, Northeast Regional Climate Center, Cornell University, Ithaca, NY, 93 pp. [Available online at precip.eas.edu/docs/xprecip_techdoc.pdf.]

Dirmeyer, P. A., and J. L. Kinter III, 2010: Floods over the U.S. Midwest: A regional water cycle perspective. $J$. Hydrometeor., 11, 1172-1181, CrossRef.

Draxler, R. R., and G. D. Hess, 1997: Description of the HYSPLIT_4 modeling system. NOAA Tech. Memo., ERL ARL-224, NOAA/Air Resources Laboratory, Silver Spring, MD, 27 pp. [Available online at www.arl.noaa.gov/documents/reports/arl-224.pdf.]

Funk, T. W., 1991: Forecasting techniques utilized by the Forecast Branch of the National Meteorological Center during a major convective rainfall event. Wea. Forecasting, 6, 548-564, CrossRef.

Gitro, C. M., 2012: WFO Binghamton, New York flash flood climatology. Eastern Region Tech. Attach., NWS ER 2012-02, NOAA/NWS, Bohemia, NY, 20 pp. [Available online at www.erh.noaa.gov/er/hq/ssd/erps /ta/ta2012-02.pdf.]

Grumm, R. H., and R. Hart, 2001a: Anticipating heavy rainfall: Forecast aspects. Preprints, Symp. on Precipitation Extremes: Prediction, Impacts, and Responses, Albuquerque, NM, Amer. Meteor. Soc., P1.30. [Available online at ams.confex.com/ams/annual2001 /webprogram/Paper17422.html.] , and __, 2001b: Standardized anomalies applied to significant cold season weather events: Preliminary findings. Wea. Forecasting, 16, 736-754, CrossRef. , and R. Holmes, 2007: Patterns of heavy rainfall in the mid-Atlantic region. Preprints, 22nd Conf. on Weather Analysis and Forecasting/18th Conf. on Numerical Weather Prediction, Park City, UT, Amer. Meteor. Soc., 5A.2. [Available online at ams.confex.com/ams /22WAF18NWP/techprogram/paper_123377.htm.]

Hart, R. E., and R. H. Grumm, 2001: Using normalized climatological anomalies to rank synoptic-scale events objectively. Mon. Wea. Rev., 129, 2426-2442, CrossRef.

James, R. P., J. M. Fritsch, and P. M. Markowski, 2005: Environmental distinctions between cellular and slabular convective lines. Mon. Wea. Rev., 133, 2669-2691, CrossRef.

Jessup, S. M., and A. T. DeGaetano, 2008: A statistical comparison of the properties of flash flooding and nonflooding precipitation events in portions of New York and Pennsylvania. Wea. Forecasting, 23, 114130, CrossRef. 
, and S. J. Colucci, 2012: Organization of flash-floodproducing precipitation in the northeast United States. Wea. Forecasting, 27, 345-361, CrossRef.

Jurewicz, M. L., Sr., 2012: The historic heavy rainfall and flooding events of 7-8 September 2011 across the midAtlantic and northeastern states. Preprints, 37th Annual Meeting, Madison, WI, Natl. Wea. Assoc., B5.2. [Available online at nwas.org/meetings/abstracts/ display.php?id=1352h.]

Kidder, S. Q., and A. S. Jones, 2007: A blended satellite total precipitable water product for operational forecasting. J. Atmos. Oceanic Technol., 24, 74-81, CrossRef.

LaPenta, K. D., and Coauthors, 1995: The challenge of forecasting heavy rain and flooding throughout the Eastern Region of the National Weather Service. Part I: Characteristics and events. Wea. Forecasting, 10, 7890, CrossRef.

Lawrence, B. A., M. I. Shebsovich, M. J. Glaudemans, and P. S. Tilles, 2003: Enhancing precipitation estimation capabilities at National Weather Service field offices using multi-sensor precipitation data mosaics. Preprints, 19th Conf. on Interactive Information Processing Systems for Meteorology, Oceanography, and Hydrology, Long Beach, CA, Amer. Meteor. Soc., 15.1. [Available online at ams.confex.com/ams/pdfpapers/54867.pdf.]

Maddox, R. A., C. F. Chappell, and L. R. Hoxit, 1979: Synoptic and meso- $\alpha$ scale aspects of flash flood events. Bull. Amer. Meteor. Soc., 60, 115-123, CrossRef.

Magsig M. A., and E. M. Page, 2002: Development and implementation of the NWS warning event simulator version 1.0. Preprints, Interactive Symposium on AWIPS, Orlando, FL, Amer. Meteor. Soc., J8.10. [Available online at ams.confex.com/ams/annual2002 /webprogram/Paper27993.html.]

Mahoney, K. M., and G. M. Lackmann, 2007: The effect of upstream convection on downstream precipitation. Wea. Forecasting, 22, 255-277, CrossRef.

MARFC, cited 2013: Top 20 individual flood events. [Available online at www.erh.noaa.gov/marfc/Rivers /FloodClimo/Top_Flood_Crests/Top20_PointsOneEven t.php.]

Moore, B. J., P. J. Neiman, F. M. Ralph, and F. E. Barthold, 2012: Physical processes associated with heavy flooding rainfall in Nashville, Tennessee, and vicinity during 1-2 May 2010: The role of an atmospheric river and mesoscale convective systems. Mon. Wea. Rev., 140, 358-378, CrossRef.

Moore, J. T., and G. E. VanKnowe, 1992: The effect of jetstreak curvature on kinematic fields. Mon. Wea. Rev., 120, 2429-2441, CrossRef.

Nielsen, J. W., 1989: The formation of New England coastal fronts. Mon. Wea. Rev., 117, 1380-1401, CrossRef.

NOAA, 1995-2012: Storm Data. [Available online at www.ncdc.noaa.gov/IPS/sd/sd.html.]
, cited 2014: Weather-Ready Nation. [Available online at www.nws.noaa.gov/com/weatherreadynation/\#.U01 VmVfE55U.]

NWS, cited 2011. National Weather Service instruction 10922: Weather forecast office hydrologic products specification. [Available online at www.nws.noaa.gov /directives/sym/pd01009022curr.pdf.] , cited 2012a: Natural hazard statistics. [Available online at www.weather.gov/om/hazstats.shtml.] , cited 2012b: Hurricane Irene, August 21-30, 2011. NWS service assessment, $129 \mathrm{pp}$. [Available online at www.nws.noaa.gov/om/assessments/pdfs/Irene2012.pdf]. , 2012c: Remnants of Tropical Storm Lee and the Susquehanna River Basin flooding of September 6-10, 2011. NWS Eastern Region service assessment, 64 pp. [Available online at www.nws.noaa.gov/om lassessments/pdfs/LeeSusquehanna12.pdf].

Ralph, F. M., P. J. Neiman, and G. A. Wick, 2004: Satellite and CALJET aircraft observations of atmospheric rivers over the eastern North Pacific Ocean during the winter of 1997/98. Mon. Wea. Rev., 132, 1721-1745, CrossRef.

, and R. Rotunno, 2005: Dropsonde observations in low-level jets over the northeastern Pacific Ocean from CALJET-1998 and PACJET-2001: Mean verticalprofile and atmospheric-river characteristics. Mon. Wea. Rev., 133, 889-910, CrossRef.

Saha, S., and Coauthors, 2006: The NCEP Climate Forecast System. J. Climate, 19, 3483-3517, CrossRef. , and _ 2010: The NCEP Climate Forecast System Reanalysis. Bull. Amer. Meteor. Soc., 91, 10151057, CrossRef. , and _ 2014: The NCEP Climate Forecast System version 2. J. Climate, 27, 2185-2208, CrossRef.

Seo, D.-J., 1998: Real-time estimation of rainfall fields using radar rainfall and rain gauge data. J. Hydrol., 208, 37-52, CrossRef.

Suro, T. P., G. D. Firda, and C. O. Szabo, 2009: Flood of June 26-29, 2006, Mohawk, Delaware, and Susquehanna River Basins, New York. U. S. Geological Survey Open-File Report 2009-1063, 354 pp. [Available online at pubs.usgs.gov/ofr/2009/1063.]

Stuart, N. A., and R. H. Grumm, 2009: The use of ensemble and anomaly data to anticipate extreme flood events in the northeastern United States. Natl. Wea. Dig., 33, 185-202. [Available online at www.nwas.org/digest/ papers/2009/Vol33No2/Stuart_Grumm_pg185.pdf.]

Zhu, Y., and R. E. Newell 1998: A proposed algorithm for moisture fluxes from atmospheric rivers. Mon. Wea. Rev., 126, 725-735, CrossRef. 